University of Wollongong

Research Online

Faculty of Science - Papers (Archive)

Faculty of Science, Medicine and Health

$1-1-2007$

\title{
Structural history of the Greenvale Province, north Queensland: Early Palaeozoic extension and convergence on the Pacific margin of Gondwana
}

Christopher L. Fergusson

University of Wollongong, cferguss@uow.edu.au

R A Henderson

James Cook University

I. W. Withnall

Dept.of Natural Resources and Mines, Qld.

C M Fanning

Australian National University

Follow this and additional works at: https://ro.uow.edu.au/scipapers

Part of the Life Sciences Commons, Physical Sciences and Mathematics Commons, and the Social and Behavioral Sciences Commons

\section{Recommended Citation}

Fergusson, Christopher L.; Henderson, R A; Withnall, I. W.; and Fanning, C M: Structural history of the Greenvale Province, north Queensland: Early Palaeozoic extension and convergence on the Pacific margin of Gondwana 2007, 573-595.

https://ro.uow.edu.au/scipapers/3023

Research Online is the open access institutional repository for the University of Wollongong. For further information contact the UOW Library: research-pubs@uow.edu.au 


\title{
Structural history of the Greenvale Province, north Queensland: Early Palaeozoic extension and convergence on the Pacific margin of Gondwana
}

\begin{abstract}
The southeastern Georgetown Inlier (Greenvale Province) consists of Early Palaeozoic metamorphic rocks in fault contact along the Lynd Mylonite Zone with the Palaeoproterozoic to Mesoproterozoic craton of northeastern Australia. It has a central assemblage of metamorphosed silicic volcanic and sedimentary rocks considered equivalent to the Late Cambrian to Early Ordovician Seventy Mile Range Group that developed in an extensional backarc in the Charters Towers Province to the southeast. In the western part of the Greenvale Province the Oasis Metamorphics has a U-Pb zircon SHRIMP metamorphic age of $476 \pm 5 \mathrm{Ma}$ and is intruded by the granodioritic Lynwater Complex with U-Pb zircon ages of $486 \pm 5$ $\mathrm{Ma}$ and $477 \pm 6 \mathrm{Ma}$. These ages are consistent with these rocks forming basement and intrusive equivalents to the extensional volcanic basin. Existing geochronological constraints on the Halls Reward domain, located at the eastern margin of the province, are consistent with it being basement to the extensional basin. Several domains are recognised in the Greenvale Province with either dominantly steep or low to moderate dips of the main foliation and each experienced multiple deformation with locally up to four overprinting structural phases. Steepening of foliation in several of the domains is attributed to contractional deformation in the Early Silurian that is inferred to have overprinted low-angle foliation developed during extensional tectonics in the backarc setting. Contractional deformation related to the Early Silurian Benambran Orogeny is considered responsible for multiple deformation in the Greenvale Province and reactivation of domain-bounding faults.
\end{abstract}

\section{Keywords}

Structural, history, Greenvale, Province, north, Queensland, Early, Palaeozoic, extension, convergence, Pacific, margin, Gondwana, GeoQUEST

\section{Disciplines}

Life Sciences | Physical Sciences and Mathematics | Social and Behavioral Sciences

\section{Publication Details}

Fergusson, C. L., Henderson, R., Withnall, I. and Fanning, C. (2007). Structural history of the Greenvale Province, north Queensland: Early Palaeozoic extension and convergence on the Pacific margin of Gondwana. Australian Journal of Earth Sciences, 54 (4), 573-595. 


\title{
Structural history of the Greenvale Province, north Queensland: Early Palaeozoic extension and convergence on the Pacific margin of Gondwana
}

\author{
C. L. FERGUSSON ${ }^{1 *}$, R. A. HENDERSON² ${ }^{2}$ I. W. WITHNALL ${ }^{3}$ AND C. M. FANNING ${ }^{4}$ \\ ${ }^{1}$ School of Earth and Environmental Sciences, University of Wollongong, NSW 2522, \\ Australia \\ ${ }^{2}$ School of Earth Sciences, James Cook University, Townsville, QLD 4811, Australia \\ ${ }^{3}$ Geological Survey of Queensland, Natural Resources Sciences, Department of Natural \\ Resources and Mines, 80 Meiers Road, Indooroopilly QLD 4068, Australia \\ ${ }^{4}$ Research School of Earth Sciences, The Australian National University, Canberra, ACT \\ 0200, Australia
}

*Corresponding author: cferguss@uow.edu.au

Phone 0242213860

Fax 0242214250

Running Title: Structural history of the Greenvale Province

The southeastern Georgetown Inlier (Greenvale Province) consists of Early Palaeozoic metamorphic rocks in fault contact along the Lynd Mylonite Zone with the Palaeoproterozoic to Mesoproterozoic craton of northeastern Australia. It has a central assemblage of metamorphosed silicic volcanic and sedimentary rocks considered equivalent to the Late Cambrian to Early Ordovician Seventy Mile Range Group that developed in an extensional backarc in the Charters Towers Province to the southeast. In the western part of the Greenvale Province the Oasis Metamorphics has a U-Pb zircon SHRIMP metamorphic age of $476 \pm 5$ $\mathrm{Ma}$ and is intruded by the granodioritic Lynwater Complex with U-Pb zircon ages of $486 \pm 5$ $\mathrm{Ma}$ and $477 \pm 6 \mathrm{Ma}$. These ages are consistent with these rocks forming basement and intrusive equivalents to the extensional volcanic basin. Existing geochronological constraints on the Halls Reward domain, located at the eastern margin of the province, are consistent with it being basement to the extensional basin. Several domains are recognised in the Greenvale Province with either dominantly steep or low to moderate dips of the main foliation and each experienced multiple deformation with locally up to four overprinting structural phases. Steepening of foliation in several of the domains is attributed to contractional deformation in the Early Silurian that is inferred to have overprinted low-angle foliation developed during extensional tectonics in the backarc setting. Contractional deformation related to the Early Silurian Benambran Orogeny is considered responsible for multiple deformation in the Greenvale Province and reactivation of domain-bounding faults.

KEY WORDS: Contractional deformation, extensional tectonics, metamorphic rocks, north Queensland, Palaeozoic, U-Pb zircon ages, Tasman Line.

\section{INTRODUCTION}

The Tasman Orogenic Zone is considered an accretionary orogen formed by dominantly convergent margin related processes involving extensional and contractional orogenesis, widespread magmatic activity and sedimentary basin evolution (Coney et al. 1990; Collins 
2002; Gray et al. 2003; Glen 2005). In northeastern Australia, the Tasman Orogenic Zone is divided into several units including the Thomson Fold Belt, and the Broken River and Hodgkinson Provinces (Figure 1). The exposed part of the Thomson Fold Belt includes the Anakie Inlier, Charters Towers Province, and the southeastern part of the Georgetown Inlier herein termed the Greenvale Province. On the basis of reconnaissance K-Ar, Rb-Sr and chemical dating of zircon and monazite it has been inferred that the Delamerian Orogeny at 510-500 Ma was the major metamorphic and deformational event in the Halls Reward Metamorphics in the eastern Greenvale Province (Nishiya et al. 2003). This is consistent with $\mathrm{K}$-Ar ages of $500 \mathrm{Ma}$ for metamorphic cooling from the Anakie Metamorphic Group in the Anakie Inlier (Withnall et al. 1996).

We have conducted a structural transect across the structural grain of the Greenvale Province with the aim of resolving the nature of the Early Palaeozoic deformation history and tectonic setting of the Early Palaeozoic margin. Several domains are recognised each with distinctive structural histories and having either dominant steeply dipping or low-angle orientation of the main foliation. In the western part of the Greenvale Province three new SHRIMP U-Pb zircon ages provide constraints on the depositional, plutonic and deformational history. These new data indicate significant Early Ordovician foliation development in the western Greenvale Province and require reassessment of the significance of the Delamerian Orogeny in northeastern Australia. We present a new interpretation of the Early Palaeozoic tectonic history of the Tasman Orogenic Zone in northeastern Australia and also reassess the significance of the Tasman Line, the contact between the Tasman Orogenic Zone and the Palaeoproterozoic to Mesoproterozoic craton (Direen \& Crawford 2003).

\section{REGIONAL SETTING AND LITHOSTRATIGRAPHY}

Three main assemblages of Palaeozoic and older age rocks occur in the Georgetown Inlier and adjacent Broken River Province near Greenvale, north Queensland: (1) Palaeoproterozoic to Early Mesoproterozoic Einasleigh Metamorphics of the Georgetown Inlier, (2) Early Palaeozoic metamorphic units and intrusions of the southeast Georgetown Inlier, herein referred to as the Greenvale Province, and (3) slightly metamorphosed to unmetamorphosed sedimentary and volcanic units of the Broken River Province (Withnall et al. 1997). The Einasleigh Metamorphics are a unit dominated by biotite gneiss and calc-silicate gneiss; minor leucocratic gneiss have ages of 1700-1550 Ma in the area immediately west of the Lynd Mylonite Zone (Black et al. 2005; Figure 1).

In the Greenvale Province, Early Palaeozoic metamorphic rocks have been divided into a number of rock units whose lithostratigraphy, metamorphism and structure has been described by Withnall (1989), Withnall et al. $(1997,2002)$ and outlined in Table 1. Several domains are recognised from west to east across the northerly to northeasterly trending structural grain away from the Palaeoproterozoic to Early Mesoproterozoic craton (Figure 2).

The Lynd domain lies between the Lynd Mylonite Zone and the Balcooma Mylonite Zone and consists of a metamorphic unit (Oasis Metamorphics) and deformed plutonic rocks (Lynwater Complex). These units were recognised by Withnall et al. (2002) who suggested that they were likely to be either Neoproterozoic or Early Palaeozoic rather than part of the Palaeoproterozoic-Mesoproterozoic Einasleigh Metamorphics (Withnall 1989; Withnall et al. 1997). Confirmation of this younger age is provided by new $\mathrm{U}-\mathrm{Pb}$ zircon ages reported herein that indicate the Oasis Metamorphics were both metamorphosed and intruded by the Lynwater Complex in the Early Ordovician.

The Balcooma domain is located between the Balcooma Mylonite Zone in the west and the northeast-trending Early Silurian Dido Tonalite in the east. It is dominated by the Early 
Palaeozoic metavolcanic and metasedimentary succession of the Balcooma Metavolcanic Group, considered an equivalent of the Upper Cambrian to Lower Ordovician Seventy Mile Range Group in the Charters Towers Province (Huston 1990; Withnall et al. 1991, 1997). A metavolcanic assemblage, the Lucky Creek Metamorphic Group, consists of mafic to silicic volcanic and volcaniclastic rocks and dominates the Lucky Creek domain east of the Dido Tonalite (Withnall 1989, 2004). The eastern part of the Lucky Creek Metamorphic Group consists mainly of the Paddys Creek Phyllite that has a more complex structural history than other units assigned to the group and is separated as the Paddys Creek domain (Tables 1, 2). The Halls Reward domain consists of the Halls Reward Metamorphics and the Boiler Gully Complex and lies between the Nickel Mine and Halls Reward Faults (Figure 2).

East and southeast of the Georgetown Inlier is the Broken River Province with two main subprovinces (Arnold \& Henderson 1976). The western Graveyard Creek Subprovince has a thick Early Ordovician to Carboniferous sedimentary assemblage overlying Early Palaeozoic mafic and silicic volcanics (Donaldsons Well Volcanics), related tonalite (e.g. Saddington Tonalite) and mafic/ultramafic basement (Gray Creek Complex; Withnall \& Lang 1993). These rocks developed in a continental margin setting with the Silurian to Devonian units interpreted as part of a forearc basin (Henderson 1987). The eastern Camel Creek

Subprovince is dominated by highly deformed Ordovician to Devonian turbidite successions with lesser chert and mafic volcanics that have been interpreted as part of an east-facing subduction complex (Henderson 1987). A magmatic arc associated with both these features may be represented by Palaeozoic intrusive complexes to the west in Palaeozoic and Precambrian metamorphics (Henderson 1980).

\section{STRUCTURAL TRANSECT}

We describe the main structural features along a west to east transect across the Greenvale Province (Figures 2, 3); the structural succession is summarised in Table 2, although it is important to note that deformations are specific to individual domains and are not necessarily matched across the whole transect. The Lynd Mylonite Zone, marking the western extent of Palaeozoic metamorphics (Figure 2), is represented by intensely foliated granitic gneiss with steeply dipping to vertical foliation that strikes north-northeast (mean of $80^{\circ} / 308^{\circ}$ from four measurements). Exposure is limited in the transect area and no detailed information on shear sense is available, but $10 \mathrm{~km}$ along the mylonite zone to the south-southwest, just beyond the map area in Figure 2, Withnall $(1989$, p. 89) noted an east-over-west shear sense based on sigmoidal asymmetry in feldspar porphyroclasts with a steeply pitching lineation in the foliation. To the west, in the Einasleigh Metamorphics, foliation is much weaker and trends easterly at a high angle to the mylonite zone. East of the Lynd Mylonite Zone, the Oasis Metamorphics contain two foliations (Table 2) with the earlier layering/foliation defining the most obvious structure and defined by aligned diopside and hornblende in calc-silicate gneiss, biotite, quartz and feldspar in pegmatite, biotite and quartz in schist and gneiss, and amphibole in amphibolite. The main foliation $\left(\mathrm{S}_{\mathrm{g}}\right)$ along with lithostratigraphic units is tightly folded by plunging $F_{2}$ that overall verge west on the eastern limb of a largescale antiform (Figures 3, 4a-d). Amphibolite metamorphism accompanied the $\mathrm{D}_{1}$ deformation in the Oasis Metamorphics with granitic veins and segregations formed subparallel to $\mathrm{S}_{\mathrm{g}}$ and also along the axial planes of rare mesoscopic $F_{2}$ folds. Larger lenticular granitic masses are present throughout the metamorphics and contain weak to locally strong foliation (labelled $\mathrm{S}_{\mathrm{f}}$, Figure $4 c)$. No pervasive fabric development accompanied $\mathrm{D}_{2}$ indicating that it was not accompanied by an appreciable metamorphic overprint of pre-existing mineralogies. The meta-igneous 
Lynwater Complex contains a steeply dipping, northerly striking foliation defined by aligned quartz, feldspar and biotite in addition to amphibolite enclaves.

The Balcooma Mylonite Zone consists of mylonitised rocks of the Oasis Metamorphics and metarhyolite of the Balcooma Metavolcanic Group (Figures 4e, 5, 6a). It is at least $1 \mathrm{~km}$ in width and in the area of Figure 5 has been offset by several easterly trending faults with apparent dextral strike-slip displacements of up to $2 \mathrm{~km}$ (Withnall 2004). Rocks in the mylonite zone contain a ubiquitous, intense foliation (S-plane) overprinted locally by an obliquely orientated, widely spaced foliation (C-plane) indicative of sinistral shear (Figures 5, 6a).

Structure of the Balcooma Metavolcanic Group has been studied in detail around the Balcooma massive sulphide deposit some $20 \mathrm{~km}$ northeast of the area shown in Figure 5 by Huston (1990) and Withnall et al. (1991) with more regional work undertaken by Withnall (1989). Huston (1990) recognised four deformations with the main deformation $\left(\mathrm{D}_{2}\right)$ responsible for the prominent foliation evident in the assemblage and near isoclinal folding (Withnall et al. 1991; Table 2). We have mapped dominant $S_{2}$ in the Balcooma Metavolcanic Group (Figure 4f-h) that grades into the intense mylonitic foliation of the Balcooma Mylonite Zone implying that the $\mathrm{D}_{2}$ deformation and sinistral movement along the boundary fault were at least partly overlapping. Note that the northeasterly trend of the Balcooma Metavolcanic Group represented in Figure 5 is a local feature; regionally the unit trends north-northeasterly (Withnall 1989). Amphibolite facies metamorphism is indicated by widespread staurolite and andalusite in pelitic schist aligned along the main $S_{2}$ foliation and associated with the $\mathrm{D}_{2}$ deformation north of the transect area (Withnall 1989).

The Dido Tonalite of Early Silurian age (Bain et al. 1997) has a weak to locally strong foliation trending subparallel to the northeast trend of the elongate pluton and typically steeply dipping that was considered synchronous with intrusion (Withnall 1989). The steep orientation of the foliation is consistent with contractional deformation.

Metavolcanic and metavolcaniclastic units of the Eland Metavolcanics in the Lucky Creek domain (Figure 7) have an intense foliation, $S_{2}$, defined by chlorite, muscovite and actinolite with hornblende at higher metamorphic grades in addition to flattened and stretched fragments in metasandstone and metaconglomeratic units (Figure $6 \mathrm{~b}, \mathrm{c}$ ). $\mathrm{S}_{1}$ is rarely preserved (Table 2). The $S_{2}$ foliation dips mainly steeply to the northwest but is folded about $F_{3}$ which plunge moderately to the southwest (Figures 7, 8a). A strong lineation is formed from intersection of early layering with the main foliation and also from stretching of lithic fragments and mineral elongation consistent with high strain (Withnall 1989). Lineation is moderately to steeply plunging to the southwest (Figure 8b). Locally in the Eland Metavolcanics shear bands are developed at $c a 20^{\circ}$ oblique to $\mathrm{S}_{2}$ (Figures $6 \mathrm{~d}, 8 \mathrm{c}$ ) and have mainly a dextral shear sense. When unfolded to the west the dextral shear bands imply westover-east transport consistent with higher metamorphic grade to the west. In the eastern part of the domain upright $\mathrm{F}_{3}$ folds plunge at $40^{\circ}$ or less (Table 2, Figure $8 \mathrm{~d}$ ) and indicate that $\mathrm{S}_{2}$ initially formed at a moderate to low inclination. Overall the Paddys Creek Phyllite has a lower metamorphic grade than the Lucky Creek domain but exhibits a more complicated structural history with four main deformations (Table 2, Figures 8e-h, 9, 10a, b). The low dip of $\mathrm{S}_{2}$ in this domain and the metapelitic lithology has resulted in abundant mesoscopic $\mathrm{F}_{3}$ folds.

In the Halls Reward domain, mafic to ultramafic rocks and the Halls Reward Metamorphics both have one main foliation $\left(\mathrm{S}_{2}\right.$, Table 2, Figure 11, Arnold \& Rubenach 1976). $S_{2}$ is mainly east-west striking and steeply dipping to the north with moderate north plunging $\mathrm{L}_{2}$ lineations (Figures 11, 12a, b). It is folded about northerly trending late folds (Figure 12a, c) although further southeast $\mathrm{S}_{2}$ is north-northeast trending and steeply dipping (Figure 12d). Amphibolite facies metamorphism was synchronous with the major deformation 
(Withnall 1989). The Nickel Mine Fault is expressed as a mylonite zone between the Halls Reward Metamorphics and the Paddys Creek Phyllite with foliation dipping steeply to the west and S and C planes indicating west-over-east shearing (Figure 10c). The Halls Reward Fault is steeply dipping with a strongly deformed mylonite zone up to $200 \mathrm{~m}$ wide (Withnall 1989). Several mylonite zones also occur west of the Halls Reward Fault and have a foliation that overprints $\mathrm{S}_{2}$ and dips gently to the west (Figure 12e) with $\mathrm{S}-\mathrm{C}$ planes and shear bands indicating southwest transport (Figure 10d).

\section{GEOCHRONOLOGY}

We selected one sample from the Oasis Metamorphics and two samples from the Lynwater Complex to obtain ages on the metamorphic and igneous history. A further sample from the Lucky Creek Metamorphic Group contained no zircons. Zircons were separated using standard techniques (crushing and desliming, magnetic separation, heavy liquids and hand picking). Cathodoluminescence images (CL) taken prior to analysis were used to target specific areas within the sectioned zircon grains. Analysis was undertaken on the sensitive high-resolution ion microprobe (SHRIMP) at the Research School of Earth Sciences, The Australian National University following techniques given by Williams (1998 and references therein). Analyses consist of six scans through the mass range with a spot size of ca $20 \mu \mathrm{m}$. $\mathrm{U} / \mathrm{Pb}$ ratios are determined by reference to $1099 \mathrm{Ma}$ Duluth Gabbro zircon grains (sample FC1, Paces \& Miller 1993). Data are reduced using the SQUID Excel Macro of Ludwig (2000), uncertainties are given at the one sigma level with weighted average age uncertainties at the 95\% confidence level; plots and calculations using ISOPLOT/EX (Ludwig 1999). Ages greater than around $800 \mathrm{Ma}$ have common $\mathrm{Pb}$ correction based on the measured ${ }^{204} \mathrm{~Pb} /{ }^{206} \mathrm{~Pb}$ ratios, whereas for ages less than around $800 \mathrm{Ma}$ common $\mathrm{Pb}$ is corrected using measured ${ }^{207} \mathrm{~Pb} /{ }^{206} \mathrm{~Pb}$ and ${ }^{238} \mathrm{U} /{ }^{206} \mathrm{~Pb}$ ratios (Tera \& Wasserburg 1972; Williams 1998).

\section{Results}

Sample IWGT016 is calc-silicate-bearing gneiss from the Oasis Metamorphics. The sample was taken from an isolated outcrop, but elsewhere along the creek in which it occurs, similar rocks form 'beds' about $10-30 \mathrm{~cm}$ thick, interlayered with fine-grained, diffusely laminated, hornblende-biotite to biotite schist and locally thin marble beds. In the field, these rocks were interpreted to have originally been slightly calcareous or dolomitic, feldspathic sandstone beds within a sedimentary sequence represented by the biotite schist and marble. Amphibolite layers, commonly thin and laminated, are also common. The sample is diffusely laminated and consists of $40-50 \%$ quartz, 30-40\% plagioclase, subsidiary (about $10 \%$ each) diopside and hornblende and 1-2\% titanite. Plagioclase occurs as discrete subequant grains up to $1 \mathrm{~mm}$ across, but the quartz forms granular mosaics with individual subgrains about $0.25 \mathrm{~mm}$ across or less. No textures that could be ascribed to either a sedimentary or igneous origin are preserved because of the degree of metamorphism and deformation. The diffuse layering is tectonic in origin.

Zircons from this sample are subhedral with complex internal structure reflecting a multiphase history. Many have zoned interiors interpreted to reflect a magmatic precursor that gives rise to the subhedral elongate shape, with thin (bright CL) metamorphic overgrowths forming subround terminations (Figure 13a, b). Analyses of the central areas to grains include minor clusters at $1300-1250 \mathrm{Ma}, 1200-1150 \mathrm{Ma}$ and 540-520 Ma (Table 3) indicating a detrital signature. Most importantly 14 rim analyses give a weighted mean ${ }^{206} \mathrm{~Pb} /{ }^{238} \mathrm{U}$ age of 
$476 \pm 5 \mathrm{Ma}(\mathrm{MSWD}=0.59)$ for the final growth phase (Figures 13a, b, 14a), which is interpreted as the timing of $\mathrm{D}_{1}$ metamorphism. Due to the complex nature of the grains a number of analyses overlap two different zircon growth periods. Analyses 6.1, 8.1 and 9.1 are poorly sited and these have been excluded from any of the plots or calculations and are shown in italics in the tabulation of data. This study concentrated on resolving the age of the metamorphic rims and further work would be needed to provide a full provenance spectrum.

Samples IWGT207 and IWGT238 are both from the Lynwater Complex. Sample IWGT238 is a well-foliated hornblende-biotite tonalite with subhedral grains of oscillatory zoned magmatic zircon (Figure 13c). Some inherited zoned igneous cores range to $2480 \mathrm{Ma}$, with most indicating Mesoproterozoic ages (Figure 13c), but a dominant group of analyses form a peak at $485 \mathrm{Ma}$ (Table 3). A weighted mean ${ }^{206} \mathrm{~Pb} /{ }^{238} \mathrm{U}$ age for 13 analyses gives $486 \pm$ $5 \mathrm{Ma}(\mathrm{MSWD}=0.76$, Figure 14b). Sample IWGT207 is a muscovite-biotite orthogneiss with in general a simple population of zoned igneous zircon. In CL detail, there appears to be a range of magmatic internal structures with zoned zircon overgrowths formed on existing zoned igneous zircon (Figure 13d). The data correspondingly shows significant dispersion on the Tera Wasserburg plot (Figure 14c) and is interpreted to result from combination of slightly older magmatic zircon (ca 500-490 Ma) mixed with the dominant zoned magmatic population. A weighted mean of 16 analyses that form the dominant peak yield a ${ }^{206} \mathrm{~Pb} /{ }^{238} \mathrm{U}$ age of $477 \pm 6 \mathrm{Ma}(\mathrm{MSWD}=1.7)$ and is considered the intrusive age of this tonalite body.

The Oasis Metamorphics and the Lynwater Complex are clearly not part of the Palaeoproterozoic - Early Mesoproterozoic Einasleigh Metamorphics as previously thought (Withnall 1989; Withnall et al. 1997). Two of the samples have an inherited component of Late Mesoproterozoic age as found in other metasedimentary successions in the region including the Halls Reward Metamorphics, Anakie Metamorphic Group, Cape River and Argentine Metamorphics (Fergusson et al. 2001, unpub. data; Nishiya et al. 2003). However the age of $\mathrm{D}_{1}$ metamorphism in the Oasis Metamorphics and associated syntectonic granitoid intrusions, represented mainly by the Lynwater Complex, is in the range 485-475 Ma (Early Ordovician).

\section{DISCUSSION}

\section{Location of the Tasman Line}

SHRIMP U-Pb zircon ages of 1700-1550 Ma demonstrate that the Einasleigh Metamorphics west of the Lynd Mylonite Zone are part of the Palaeoproterozoic to Early Mesoproterozoic craton (Black et al. 2005). U-Pb zircon ages reported herein in addition to those of Withnall et al. (1991) for the Balcooma Metavolcanic Group and ages by various techniques reported by Nishiya et al. (2003) for the Halls Reward Metamorphics show that the Greenvale Province is part of an Early Palaeozoic orogenic belt and that the Palaeoproterozoic to Early Mesoproterozoic craton lies west of the Lynd Mylonite Zone. Unlike the Palmerville Fault further north (Shaw et al. 1987), which has the Precambrian craton thrust eastwards over Lower Palaeozoic low-grade sedimentary and volcanic rocks, the Tasman Line in the southeastern Georgetown Inlier is marked by a steeply dipping mylonite zone which according to Withnall (1989) has an east-over-west sense of shear. In contrast to central Queensland and southeastern Australia where the location and significance of the Tasman Line is unresolved (Direen \& Crawford 2003), in north Queensland it is clearly defined as the western contact of the Tasman Orogenic Zone along the Lynd Mylonite Zone in the southeast Georgetown Inlier and the Palmerville Fault at the western margin of the Hodgkinson 
Province. We concur with Direen and Crawford (2003) that the Tasman Line has no significance in terms of rifting of a Proterozoic supercontinent.

\section{Depositional development and setting}

A latest Cambrian to Early Ordovician age is inferred for the primary volcanic and associated sedimentary succession of the Balcooma Metavolcanic and Lucky Creek Metamorphic Groups. This is supported by U-Pb zircon ages (Withnall et al. 1991) and their lithological similarity with the uppermost Cambrian to Lower Ordovician Seventy Mile Range Group of the Charters Towers Province (Henderson 1986; Withnall et al. 1997). Igneous rocks in the Seventy Mile Range Group have a lower part containing mafic dykes, sills and volcanic rocks with an intraplate/rift geochemical signature overlain by voluminous volcanic units with a subduction-related signature that formed in an extensional backarc setting (Henderson 1986; Stolz 1995). Geochemistry of volcanic rocks in the Balcooma Metavolcanics is limited and scattered in tectonic affinities but published analyses, as well as more recently obtained unpublished data by the Geological Survey of Queensland, are consistent with a calc-alkaline signature for the Eland Metavolcanics, whereas the Lugano Metamorphics contain tholeiitic metabasalts (Withnall 1989). An overall extensional backarc setting is favoured for the formation of these rocks to the west of a subduction-related arc similar to the setting inferred for the Seventy Mile Range Group.

The Oasis Metamorphics contain metasedimentary and meta-igneous rocks derived from dolomitic carbonates and impure carbonate of probable shallow marine setting, shale and quartzo-feldspathic sandstone and mafic volcanic and/or intrusive rocks of tholeiitic affinities (unpublished data, Geological Survey of Queensland). They have a late Neoproterozoic to Early Palaeozoic depositional age constrained by ages of detrital zircons and the $476 \pm 5 \mathrm{Ma}$ age for metamorphic rims on zircons indicating timing of amphibolite facies metamorphism and providing an upper age limit. The primary rocks of the Oasis Metamorphics are likely to have formed along the Gondwanan margin during this interval, predating the backarc basin infill associated with the Seventy Mile Range Group and equivalents. Intrusive ages of the strongly deformed Lynwater Complex at $486 \pm 5 \mathrm{Ma}$ and $477 \pm 6 \mathrm{Ma}$ are consistent with $\mathrm{D}_{1}$ metamorphism in the adjoining Oasis Metamorphics. The Lynwater Complex is equivalent in age to the older part of the Lolworth Batholith (Hutton et al. 1997) and is overlapped in age by the subjacent Seventy Mile Range Group (Henderson 1984).

The Halls Reward Metamorphics have been considered a Proterozoic element of the southeast Georgetown Inlier (Withnall 1989) although the isotopic ages of Nishiya et al. (2003) indicate that they are much younger than previously supposed. Ages of detrital zircons, determined by a chemical U-Th-total $\mathrm{Pb}$ isochron method (CHIME), are as young as $600 \mathrm{Ma}$ with metamorphism and deformation determined from the same method on monazite along with $\mathrm{K}-\mathrm{Ar}$ mineral and $\mathrm{Rb} / \mathrm{Sr}$ whole rock and mineral ages at 510-500 Ma suggesting a late Neoproterozoic to Middle Cambrian depositional age (Nishiya et al. 2003). Primary relationships between metasedimentary rocks of the Halls Reward Metamorphics and the meta-igneous rocks of the Boiler Gully Complex are severely overprinted by intense $\mathrm{D}_{2}$ deformation (Arnold \& Rubenach 1976) and the age of the latter is no better constrained than Late Neoproterozoic to Middle Cambrian. Strongly deformed ultramafic and mafic rocks also occur in the Gray Creek Complex at the base of the Graveyard Creek Subprovince (Henderson 1987) no more than $5 \mathrm{~km}$ distant from the Halls Reward domain. The Gray Creek Complex also has experienced amphibolite facies metamorphism and is overlain by the Early Ordovician Judea Formation, which has a low-grade metamorphic history (Arnold \& Henderson 1976; Withnall \& Lang 1993). 


\section{Deformation history of the Greenvale Province}

The characteristic structural feature of much of the Greenvale Province is the development of intense syn-metamorphic foliation. West of the Dido Tonalite much of this foliation is steeply dipping although it is clear from the Oasis Metamorphics that the present steep dip is a result of tight folding in a younger contractional deformation. The U-Pb ages indicate that $\mathrm{D}_{1}$ amphibolite metamorphism in the Oasis Metamorphics is of Early Ordovician age and accompanied intrusion of the Lynwater Complex which contains intense foliation that we consider also developed at this time.

Steeply dipping intense foliation $\left(\mathrm{S}_{2}\right)$ affects the Balcooma Metavolcanic Group but the nature of an earlier deformation is difficult to resolve. In the Lucky Creek and Paddys Creek domains, folds that affected the $\mathrm{S}_{2}$ foliation have a low to moderate plunge and indicate that $\mathrm{S}_{2}$ must have had an initial low to sub-horizontal dip. Subparallel intersection and stretching lineations, which are particularly well developed in the Eland Metavolcanics, consistent with high strain associated with the $\mathrm{D}_{2}$ deformation.

The intense foliation $\left(\mathrm{S}_{2}\right)$ in the Lucky Creek domain overall dips westwards and is associated with increasing metamorphic grade towards the Cockie Spring Tonalite and the Dido Tonalite (greenschist facies in the Paddys Creek Phyllite through to amphibolite facies in the western part of the Lugano Metamorphics). Late shear bands developed along this foliation after unfolding indicate west-over-east transport consistent with the metamorphic pattern. Reactivation of the $\mathrm{S}_{2}$ foliation in a contractional setting must have followed its formation and accompanied contractional deformation $\left(\mathrm{D}_{3}\right)$ in the Lucky Creek and Paddys Creek domains. The increasing metamorphic grade is at least partly attributed to the Cockie Spring Tonalite which is intensely foliated and similar to the Lynwater Complex. We consider that steepening of the $S_{2}$ foliation in the Lucky Creek domain reflects reactivation prior to and during intrusion of the Dido Tonalite in an Early Silurian contractional regime recognised in the Greenvale Province and adjacent Broken River Province by Henderson (1987). This contractional deformation also accounts for all post- $\mathrm{D}_{2}$ deformation in the Lucky Creek and Paddys Creek domains (Table 2).

Fault zones separating domains, and at the boundaries of the Greenvale Province, show diverse movement history. They are defined mainly by steeply dipping intense foliation apart from low-angle mylonite zones in the eastern part of the Halls Reward domain. The steep dip of most fault zones is inconsistent with contractional orogenesis unless they formed either earlier as strike-slip and/or normal faults or they have been rotated to a steep dip during contractional deformation. These alternatives are difficult to evaluate given the overprinting associated with late deformation along these zones and the limited geochronology available. The last main deformation along the Lynd, Balcooma and Nickel Mine Faults are considered to represent reactivation during high-angle reverse slip and probably developed in the Early Silurian event. Sinistral strike-slip motion along the Balcooma Mylonite Zone is consistent with regional northwest-orientated contraction during the Silurian. The Balcooma Mylonite Zone is truncated by the Dido Tonalite so that movement along it predated $431 \mathrm{Ma}$ (Bain et al. 1997).

$\mathrm{Rb} / \mathrm{Sr}$ ages of whole rocks and muscovites, K/Ar ages of muscovites, and CHIME ages on monazite (Nishiya et al. 2003), have been forwarded as evidence that the Halls Reward Metamorphics and associated meta-igneous units were deformed and metamorphosed at 510 500 Ma during the Delamerian Orogeny. These rocks have an inferred age and detrital zircon age signature similar to other units in Queensland such as the Anakie Metamorphic Group (Fergusson et al. 2001). Such data are consistent with this domain representing Early 
Palaeozoic metamorphic basement that predated initiation of the backarc basin volcanic and sedimentary succession represented by the Balcooma, Lucky Creek and Paddys Creek domains in the Late Cambrian to Early Ordovician (500-470 Ma).

Early Silurian contractional deformation affected the Early Silurian Dido Tonalite (Withnall 1989) and induced uplift that generated the thick, northwest-derived Lower Silurian Graveyard Creek Conglomerate which is at the base of the thick Silurian-Devonian succession of the Graveyard Creek Subprovince (Arnold \& Henderson 1976; Henderson 1987; Withnall \& Lang 1993). This formation contains abundant metamorphic, mafic and ultramafic clasts and demonstrates that the Greenvale Province was being actively uplifted and eroded at this time. We also attribute overprinting deformation that rotated foliation to steep dips in the western part of the Greenvale Province, multiple deformation east of the Dido Tonalite and reactivation of fault zones to this contractional deformation. These features indicate Early Silurian tectonism in northeastern Australia, referred to here as the Benambran Orogeny, and correlative with contractional tectonism in southeastern Australia on which this term is based.

\section{Low-angle foliation - evaluation of its significance}

The separation of contractional from extensional processes involved in the development of low-angle foliations in metamorphic rocks is a widely recognised problem (Harris et al. 2002). Low-angle foliation and associated recumbent folds have been documented in metamorphic rocks associated with shortening in continental collision zones such as the European Alps (Ramsay et al. 1981). In contrast, extensional processes are involved in the exhumation of rocks affected by high-pressure and/or ultra-high pressure metamorphism as found in Norway (Andersen 1998). Extensional processes are also illustrated by the development of low-angle foliation, usually with intense shearing, low-pressure metamorphism and plutonic activity, in metamorphic core complexes formed during Early Tertiary extension in the Basin and Range Province of the southwestern USA (Malavieille 1993).

The development of low-angle foliation in middle to lower upper crust rocks with accompanying amphibolite to greenschist facies metamorphism is especially problematic where evidence for either earlier high-pressure metamorphism or distinctive features associated with metamorphic core complexes are lacking. Fergusson et al. (2005) argued that the low-angle, intense foliation $\left(\mathrm{S}_{2}\right)$ and recumbent folds of the Early Palaeozoic Cape River Metamorphics, located $100 \mathrm{~km}$ south of the Greenvale Province in the Charters Towers Province, formed in an extensional tectonic setting. They also reinterpreted low-angle foliation and associated large-scale recumbent folds in the Anakie Inlier (Withnall et al. 1995; Green et al. 1998) as a result of ductile thinning involving a substantially pure shear mode of deformation in an extensional regime. No detachment faults have been identified in these examples and simple shearing type deformation is subsidiary to pure shear with pervasive ductile thinning of the middle to lower upper crust. Similar extensional metamorphic rock assemblages that lack many of the distinctive characteristics of metamorphic core complexes have been described from the Hercynian belt of Europe (Cagnard et al. 2004), the Pyrenees (Gibson 1991) and the Yukon-Tanana terrane in Alaska (Pavlis \& Sission 1993).

In the Greenvale Province, low-angle foliation developed during $\mathrm{D}_{2}$ in the Lucky Creek and Paddys Creek domains and probably also as $\mathrm{D}_{1}$ in the Lynd domain. We favour development of the low-angle foliation by dominantly pure shearing (i.e. ductile flattening) in an extensional crustal environment consistent with the regional backarc setting as argued for the Cape River Metamorphics (Fergusson et al. 2005). Subsequent contractional deformation 
has resulted in rotation of the low-angle foliation to steep dips as illustrated by the structure of the Lynd, Lucky Creek and Paddys Creek domains.

\section{Regional significance}

Based on this study, we can better place the development of the Greenvale Province in the regional Early Palaeozoic tectonic history of the northern Tasman Orogenic Zone. Rifting occurred along the Australian part of East Gondwana in the Late Neoproterozoic around 600 Ma (Direen \& Crawford 2003). It is not known if the rifted fragment was a continent such as Laurentia or a ribbon continental fragment such as the Lord Howe Rise. In northeastern Australia, sedimentation on this rifted margin is represented by the older protolith of metasedimentary rocks comprising the Anakie Metamorphic Group and accompanying interlayered mafic igneous units (Withnall et al. 1995; Fergusson et al. 2001). Equivalents of these rocks occur in the Charters Towers Province in the Cape River and Argentine Metamorphics (Fergusson et al. 2005 and unpublished data) and are identified here as the protolith of the Oasis Metamorphics.

It has been considered that northeastern Australia was affected by the Delamerian Orogeny on the basis of K-Ar mineral, $\mathrm{Rb}-\mathrm{Sr}$ mineral and whole-rock and CHIME monazite ages (Withnall et al. 1996; Nishiya et al. 2003). These reconnaissance studies need to be followed up by more systematic research including in situ dating of monazite, $\mathrm{U}-\mathrm{Pb}$ dating of zircon, monazite and titanite and $\mathrm{Ar}^{39} / \mathrm{Ar}^{40}$ dating of amphibole and micas. These mid Cambrian ages, if vindicated, indicate that the Halls Reward Metamorphics represent a basement block that was upstanding as a horst during the Early Ordovician extensional episode (Figure 15a) and was not influenced by ductile deformation that affected deeper crustal levels of the adjacent backarc basin. The Halls Reward domain includes the Boiler Gully mafic-ultramafic assemblage, the Sandalwood Serpentinite and the Stenhouse Amphibolite which may represent oceanic crust (Withnall 1989). The Oasis Metamorphics most probably represent a Neoproterozoic continental margin sedimentary package which lay beneath the extensional basin system and experienced extensional deformation (Figure 15a).

The application of extensional tectonics in north Queensland is demonstrated by the backarc basinal setting of the Late Cambrian and earliest Ordovician succession comprising the Seventy Mile Group which contains thick volcanic intervals. Metamorphic rocks of the Greenvale Province contain a record of similar type (Figure 15a). Employing the timescale of Gradstein and Hogg (2004) our new U-Pb zircon ages of 485-475 Ma provide evidence of amphibolite metamorphism and accompanying silicic intrusions in the Greenvale Province correlative with the Lancefieldian-Chewtonian graptolite ages for extensional volcanism and associated sedimentation in the Seventy Mile Range Group. For the Greenvale Province, high heat-flow and magmatism was coincident with the deep levels of a backarc rift within a regime of ductile deformation accompanied by the development of low-angle foliation. The extensional regime may reflect roll back in plate engagement and general extension of an active margin sector as described by Hamilton (1995).

This crustal tract represented by the Greenvale Province, with widespread extensional fabric development, was subsequently overprinted by Early Silurian (Benambran) contractional deformation. As suggested by Thompson et al. (2003) sectors of crust thinned by extension and weakened by long-lived thermal softening are especially prone to shortening strain generated by enhanced plate coupling during convergence. A subduction-related, Late Ordovician island arc is represented by a narrow belt of calc-alkaline volcanic rocks and volcaniclastic strata represented by the Everetts Creek Volcanics and Carriers Well Formation at the western margin of the Camel Creek Subprovince (Withnall \& Lang 1993). These rocks 
were accreted in Early Silurian contractional deformation with subsequent large-scale growth of an accretionary subduction complex in the Silurian to Devonian Camel Creek Subprovince and Hodgkinson Province (Henderson 1987).

Although there are major differences in the extent and nature of domains and rock units in the Greenvale Province, this tectonic evolution has some resemblance to that recognised in the Adelaide and Lachlan Fold Belts of southeastern Australia. Early to Middle Cambrian extensional tectonics (520-510 Ma) produced the vast marginal sea represented by oceanic and infant island arc basement of the Lachlan Fold Belt (Crawford et al. 2003a). Development of the Adelaide Fold Belt occurred in the Delamerian Orogeny arising from a relatively shortlived collision of the rifted margin with an outboard island arc terrane (Crawford et al. 2003b). An extensional tectonic regime characterised the Lachlan Fold Belt throughout the Ordovician accompanied by development of the Macquarie Arc in its northeastern part (Powell 1984; Glen et al. 1998; Squire \& Miller 2003). Blueschist metamorphism in the adjoining New England Fold Belt (Fukui et al. 1995) marks the development of an outboard subduction complex at this time.

Protolith of the Halls Reward domain could represent Early to Middle Cambrian extended crust with oceanic elements overprinted by Delamerian orogenesis. A long lived Ordovician extensional regime followed, represented by the remaining domains of the Greenvale Province and a Late Ordovician magmatic arc is also in evidence in the adjoining Broken River Province. In north Queensland, Early Silurian Benambran orogenesis terminated the proceeding extensional regime and was a relatively short-lived episode of contractional deformation as is also characteristic of the Lachlan Fold Belt.

\section{CONCLUSIONS}

A structural transect across the southeast Georgetown Inlier in conjunction with new $\mathrm{U}-\mathrm{Pb}$ zircon ages from the western part of the traverse has significant implications for the regional geology of the northern Tasman Orogenic Zone. The Tasman Line is shown to occur along the Lynd Mylonite Zone $60 \mathrm{~km}$ west of its previously defined position on the Burdekin River

Fault. In north Queensland, the Tasman Line does not represent the position of breakup of the Rodinian continent but instead is the western contact of the Tasman Orogenic Zone with the Palaeoproterozoic to Early Mesoproterozoic craton. Plutonism and amphibolite metamorphism in the Early Ordovician at ca 480-475 Ma are interpreted as part of an extensional crustal continuum represented by various rock assemblages of the region with ductilely deformed deeper levels of a backarc extensional rift setting in the Greenvale Province equivalent to the upper crustal basin fill represented by Seventy Mile Range Group of the Charters Towers Province. Ductile extensional deformation generated low-angle foliation in basement to the rift and also in the deeper parts of rift-fill volcanic and sedimentary successions. These foliations were subsequently reactivated and rotated to steeper orientations during mainly Early Silurian contractional deformation of the Benambran Orogeny.

\section{ACKNOWLEDGEMENTS}

The Australian Research Council (grant number A00103036) and the Geological Survey of Queensland funded this work with additional support from James Cook University, the University of Wollongong and The Australian National University. We are grateful to the property owners in the Lynd-Greenvale region for allowing access. Peter Johnson computer 
drafted the figures. We thank Ron Berry and David Gray whose reviews have resulted in an improved manuscript.

\section{REFERENCES}

ANDERSEN T. B. 1998. Extensional tectonics in the Caledonites of southern Norway, an overview. Tectonophysics 285, 333-351.

ARnOld G. O. \& Henderson R. A. 1976. Lower Palaeozoic history of the southwestern Broken River Province, North Queensland. Journal of the Geological Society of Australia 23, 73-93.

ARNOLD G. O. \& RUBENACH M. J. 1976. Mafic-ultramafic complexes of the Greenvale area, North Queensland: Devonian intrusions or Precambrian metamorphics? Journal of the Geological Society of Australia 23, 119-139.

Bain J. H. C., MacKenzie D. E., Withnall I. W. \& Champion D. C. 1997. SilurianDevonian. In: Bain J. H. C. \& Draper J. J. eds. North Queensland Geology, pp. 35-36. Australian Geological Survey Organisation Bulletin 240 and Queensland Geology 9.

Black L. P., Withnall I. W., Gregory P., Oversby B. S. \& Bain J. H. C. 2005. U-Pb zircon ages from leucogneiss in the Etheridge Group and their role in the early history of the Georgetown region, North Queensland. Australian Journal of Earth Sciences 52, 385-401.

CAgnard F., Gapais D., Brun J. P., GumiauX C. \& VAN DEN Driessche J. 2004. Late pervasive crustal-scale extension in the south Armorican Hercynian belt (Vendée, France). Journal of Structural Geology 26, 435-449.

CoLLINS W. J. 2002. Nature of extensional accretionary orogens. Tectonics 21, 1-12. DOI$10.1029 / 2000 \mathrm{TC} 001272$.

CONEY P. J., EDWARDS A., HiNE R., MORRSION F. \& WiNDRIM D. 1990. The regional tectonics of the Tasman orogenic system, eastern Australia. Journal of Structural Geology 12, 519 543.

Crawford A. R., Cayley R. A., Taylor D. H., Morand V. J., Gray C. M., KemP A. I. S., Wohlt K. E., VandenBerg A. H. M., Moore D. H., Maher S., Direeen N. G., EdwardS J., Donaghy A. G., ANDERSON J. A. \& Black L. P. 2003a. Neoproterozoic and Cambrian continental rifting, continent-arc collision and post-collisional magmatism. In: Birch W. ed. The Geology of Victoria. Geological Society of Australia, Victorian Division, 73-92.

Crawford A. J., MefFre S. \& SyMONDS P. A. 2003b. 120 to 0 Ma tectonic evolution of the southwest Pacific and analogous geological evolution of the 600 to $220 \mathrm{Ma}$ Tasman Fold Belt System. In: Hillis R. R. \& Müller R. D. eds Evolution and Dynamics of the Australian Plate. Geological Society of Australia Special Publication 22 and Geological Society of America Special Paper 372, 383-403.

DiREEN N. G. \& CRAwFORD A. J. 2003. The Tasman Line: where is it, what is it, and is it Australia's Rodinian breakup boundary? Australian Journal of Earth Sciences 50, 491-502.

Fergusson C. L., CARr P. F., FAnNing C. M. \& Green T. J. 2001. Proterozoic-Cambrian detrital zircon and monazite ages from the Anakie Inlier, central Queensland: Grenville and Pacific-Gondwana signatures. Australian Journal of Earth Sciences 48, 857-866.

Fergusson C. L., Henderson R. A., Lewthwaite K. J., Phillips D. \& Withnall I. W. 2005. Structure of the Early Palaeozoic Cape River Metamorphics, Tasmanides of north Queensland: evaluation of the roles of convergent and extensional tectonics. Australian Journal of Earth Sciences 52, 261-277.

Fukui S., Watanabe T., Itaya T. \& Leitch E. C. 1995. Middle Ordovician high PT metamorphic rocks in eastern Australia: evidence from K-Ar ages. Tectonics 14, 1014-1020. 
GIBSON R. L. 1991. Hercynian low-pressure-high-temperature regional metamorphism and subhorizontal foliation development in the Canigou massif, Pyrenees, France-Evidence for crustal extension. Geology 19, 380-383.

GLEN R. A. 2005. The Tasmanides of eastern Australia. In: Vaughan A. P. M., Leat P. T. \& Pankhurst R. J. eds Terrane Processes at the Margins of Gondwana. Geological Society, London, Special Publications 246, 23-96.

GLEN R. A., WALSHE J. L., BARRON L. M. \& WATKINS J. J. 1998. Ordovician convergent-margin volcanism and tectonism in the Lachlan sector of east Gondwana. Geology 26, 751-754.

Gradstein F. M. \& OGG J. G. 2004. Geologic Time Scale 2004 - why, how, and where next! Lethaia 37, 175-181.

Gray D. R., Foster D. A., Morand V. J., Willman C. E., Cayley R. A., Spaggiari C. V., TAYlor D. H., Gray C. M., VANDEnBerg A. H. M., HendrickX M. A. \& Wilson C. J. L. 2003. Structure, metamorphism, geochronology and tectonics of Palaeozoic rocks interpreting a complex, long-lived orogenic system. In: Birch W. ed. The Geology of Victoria. Geological Society of Australia, Victorian Division, 15-71.

GREen T. J., FERGUSSON C. L. \& WithnALL I. W. 1998. Refolding and strain in the Neoproterozoic - Early Palaeozoic Anakie Metamorphic Group, central Queensland. Australian Journal of Earth Sciences 45, 915-924.

HAMilton W. B. 1995. Subduction systems and magmatism. In: Smellie J. L. ed. Volcanism Associated with Extension at Consuming Plate Margins, pp. 3-28. Geological Society of London Special Publication 81.

HARRIS L. B., KOYI H. A. \& FoSSEN H. 2002. Mechanisms for folding of high-grade rocks in extensional tectonic settings. Earth-Science Reviews 59, 163-210.

HENDERSON R. A. 1980. Structural outline and summary geological history for northeastern Australia. In: Henderson R. A. \& Stephenson P. J. eds. The Geology and Geophysics of Northeastern Australia, pp. 1-26. Geological Society of Australia, Queensland Division.

HENDERSON R. A. 1986. Geology of the Mt Windsor Subprovince - a Lower Palaeozoic volcano-sedimentary terrane in the northern Tasman Orogenic Zone. Australian Journal of Earth Sciences 33, 343-364.

HENDERSON R. A. 1987. An oblique subduction and transform faulting model for the evolution of the Broken River Province, northern Tasman Orogenic Zone. Australian Journal of Earth Science 34, 237-249.

HUSTON D. L. 1990. The stratigraphic and structural setting of the Balcooma volcanogenic massive sulphide lenses, north Queensland. Australian Journal of Earth Sciences 37, 423440.

Hutton L. J., Draper J. J., Rienks I. P., Withnall I. W. \& KnUtson J. 1997. Chapter 6. Charters Towers region. In: Bain J. H. C. \& Draper J. J. eds. North Queensland Geology, pp. 165-224. Australian Geological Survey Organisation Bulletin 240 and Queensland Geology 9.

LUDWIG K. R. 1999. User's manual for Isoplot/Ex, Version 2.10, A geochronological toolkit for Microsoft Excel. Berkeley Geochronology Center Special Publication No. 1a, 2455 Ridge Road, Berkeley CA 94709, USA.

LUDWIG K. R. 2000. SQUID 1.00, A User's Manual; Berkeley Geochronology Center Special Publication. No. 2, 2455 Ridge Road, Berkeley, CA 94709, USA.

MALAVIEILLE J. 1993. Late orogenic extension in mountain belts: insights from the Basin and Range and the Late Paleozoic Variscan Belt. Tectonics 12, 1115-1130.

Nishiya T., Watanabe T., Yokoyama K. \& Kuramoto Y. 2003. New isotopic constraints on the age of the Halls Reward Metamorphics, North Queensland, Australia: Delamerian metamorphic ages and Grenville detrital zircons. Gondwana Research 6, 241-249. 
PaCes J. B. \& Miller J. D. 1993. Precise U-Pb ages of Duluth Complex and related mafic intrusions, northeastern Minnesota: Geochronological insights to physical, petrogenetic, paleomagnetic, and tectonomagmatic processes associated with the 1.1 Ga Midcontinent Rift System. Journal of Geophysical Research 98, 13997-14013.

PAVLIS T. L. \& SiSSON V. B. 1993. Mid-Cretaceous extensional tectonics of the Yukon-Tanana terrane, Trans-Alaska Crustal Transect (TACT), east-central Alaska. Tectonics 12, 103-122.

Powell C. MCA. 1984. Ordovician to earliest Silurian: marginal sea and island arc; Silurian to mid-Devonian dextral transtensional margin; Late Devonian and Early Carboniferous: continental magmatic arc along the eastern edge of the Lachlan Fold Belt. In: Veevers J. J. ed. Phanerozoic Earth History of Australia, pp. 290-340. Oxford University Press, Oxford.

RAMSAY J. G., CASEY M. \& KLIGFIELD R. 1980. Role of shear in development of the Helvetic fold-thrust belt of Switzerland. Geology 10, 439-442.

SCHEIBNer E. \& VeEVERs J. J. 2000. 19 Tasman Fold Belt System. In: Veevers J. J. ed. Billion-year earth history of Australia and neighbours in Gondwanaland, pp. 154-234. Gemoc Press, Sydney.

SHAW R. D., FAWCKNER J. F. \& Bultitude R. J. 1987. The Palmerville fault system: a major imbricate thrust system in the northern Tasmanides, north Queensland. Publication. Australian Journal of Earth Sciences 34, 69-93.

SQuire R. J. \& MiLler J. MCL. 2003. Synchronous compression and extension in East Gondwana: tectonic controls on world-class gold deposits at 440 Ma. Geology 31, 10731076.

Stolz A. J. 1995. Geochemistry of the Mount Windsor Volcanics: implications for the tectonic setting of Cambro-Ordovician volcanic-hosted massive sulphide mineralisation in northeastern Australia. Economic Geology 90, 1080-1097.

TERA F. \& WASSERBURG G. 1972. U-Th-Pb systematics in three Apollo 14 basalts and the problem of initial $\mathrm{Pb}$ in lunar rocks. Earth and Planetary Science Letters 14, 281-304.

Thompson A. B., Schulmann K., JezeK J. \& Tolar V. 2001. Thermally softened continental extension zones (arcs and rifts) as precursors to thickened orogenic belts. Tectonophysics 332, 115-141.

WILLIAMS I. S. 1998. U-Th-Pb Geochronology by Ion Microprobe. In: McKibben M. A., Shanks III W. C. \& Ridley W. I. Eds. Applications of microanalytical techniques to understanding mineralizing processes. Reviews in Economic Geology 7, 1-35.

WithNALl I. W. 1989. Precambrian and Palaeozoic geology of the southeastern Georgetown Inlier, north Queensland. Queensland Department of Mines, Report 2, 102 p.

Withnall I. W. 2004. Conjuboy 1:100 000 Geological Sheet 7860, Department of Natural Resources and Mines, Queensland.

Withnall I. W. \& Lang S. C. 1993. Geology of the Broken River Province, north Queensland. Queensland Geology 4, 289 p.

WithNall I. W., Black L. P. \& HARVEY K. J. 1991. Geology and geochronology of the Balcooma area: part of an Early Palaeozoic magmatic belt in North Queensland. Australian Journal of Earth Sciences 38, 15-29.

Withnall I. W., Blake P. R., Crouch S. B. S., Tenison Woods K., HaYward M. A., LAM J. S., GARRAD P. \& REES I. D. 1995. Geology of the southern part of the Anakie Inlier, central Queensland. Queensland Geology 7, 245 p.

Withnall I. W., Golding S. D., ReEs I. D. \& Dobos S. K. 1996, K-Ar dating of the Anakie Metamorphic Group: evidence for an extension of the Delamerian Orogeny into central Queensland. Australian Journal of Earth Sciences 43, 567-572.

Withnall I. W., Mackenzie D. E., Denaro T. J., Bain J. H. C., Oversby B. S., Knutson J., DonchaK P. J. T., Champion D. C., Wellman P., CRuikshank B. I., Sun S. S. \& Pain C. F. 1997. Chapter 3. Georgetown Region. In: Bain J. H. C. and Draper J. J. eds. North 
Queensland Geology, pp. 19-116. Australian Geological Survey Organisation Bulletin 240 and Queensland Geology 9.

Withnall I. W., Hutton L. J., Garrad P. D., Jones M. R. \& Blight R. K. J. 2002. North Queensland Gold and Base Metal Study Stage 1- Georgetown GIS. Geological Survey of Queensland, Department of Natural Resources and Mines, digital data (including explanatory notes) released on CD-ROM.

\section{FIGURES}

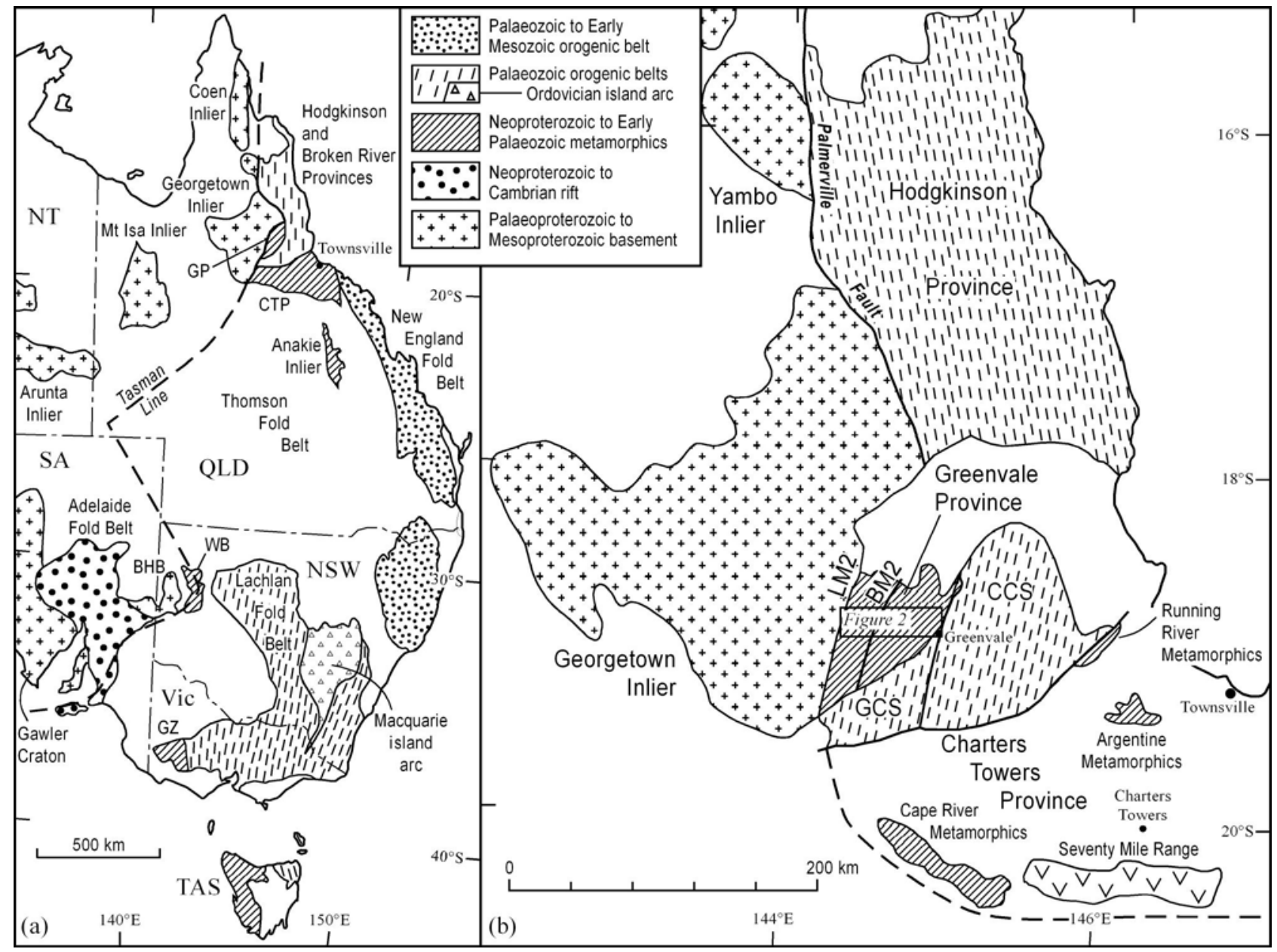

Figure 1 (a) Major elements of the Tasman Orogenic Zone in eastern Australia. Tasman Line is as shown by Scheibner and Veevers (2000) and has been questioned by Direen and Crawford (2003). Abbreviations: BHB $=$ Broken Hill Block, CTP $=$ Charters Towers Province, $\mathrm{GZ}=$ Glenelg Zone, GP = Greenvale Province (southeast Georgetown Inlier), WB = Wonominta Block. (b) Palaeozoic and older elements of the Townsville region. Abbreviations: $\mathrm{BMZ}=$ Balcooma Mylonite Zone, $\mathrm{CCS}=$ Camel Creek Subprovince, $\mathrm{GCS}=$ Graveyard Creek Subprovince, LMZ = Lynd Mylonite Zone. 


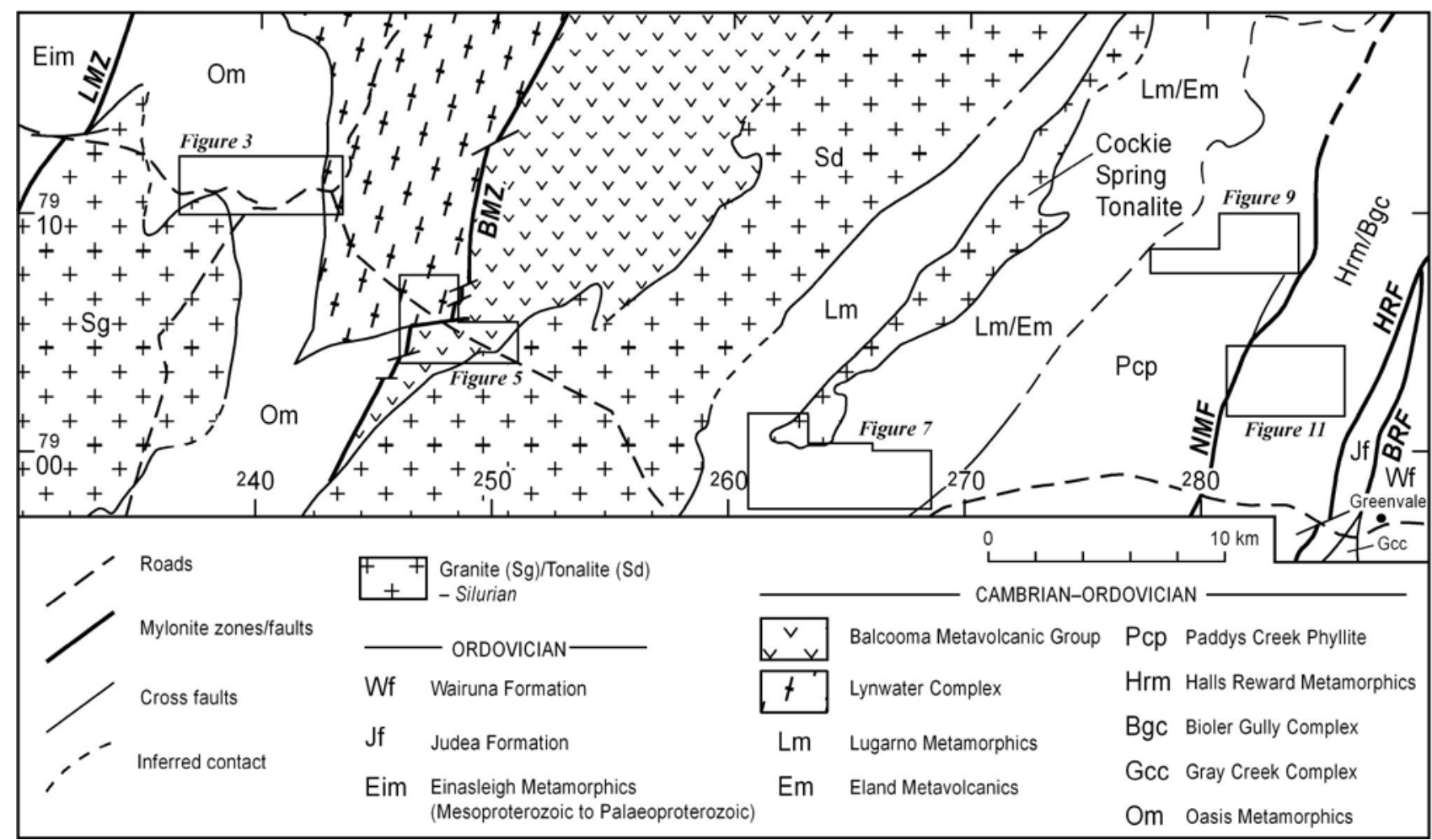

Figure 2 Regional geology of the southern Greenvale Province modified from Withnall (2004) with locations of detailed figures. Abbreviations: BMZ = Balcooma Mylonite Zone, $\mathrm{BRF}=$ Burdekin River Fault, LMZ = Lynd Mylonite Zone, NMF = Nickel Mine Fault. 


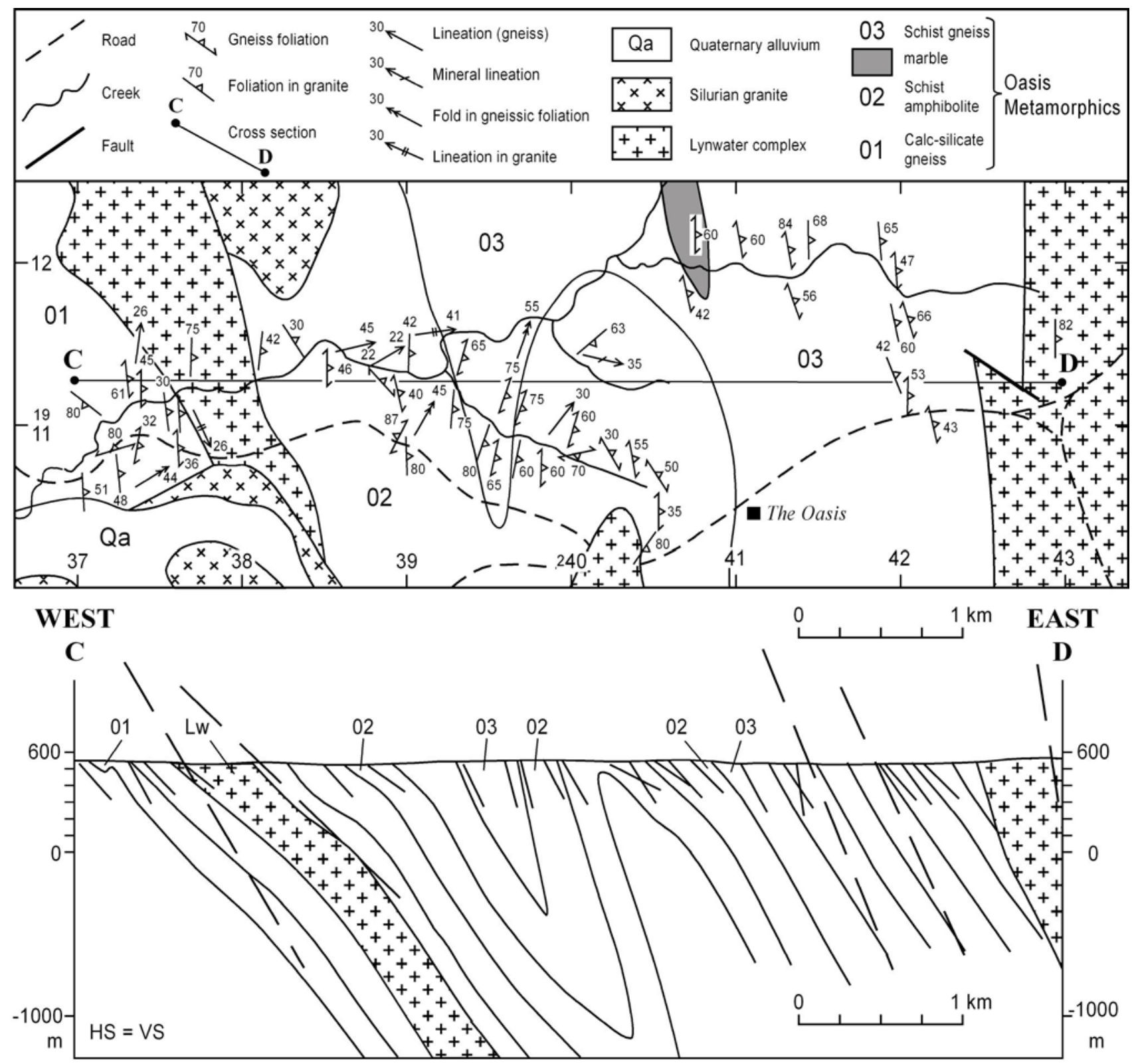

Figure 3 Map and cross section CD of 'The Lynd' area. Lw = Lynwater Complex (on cross section). 

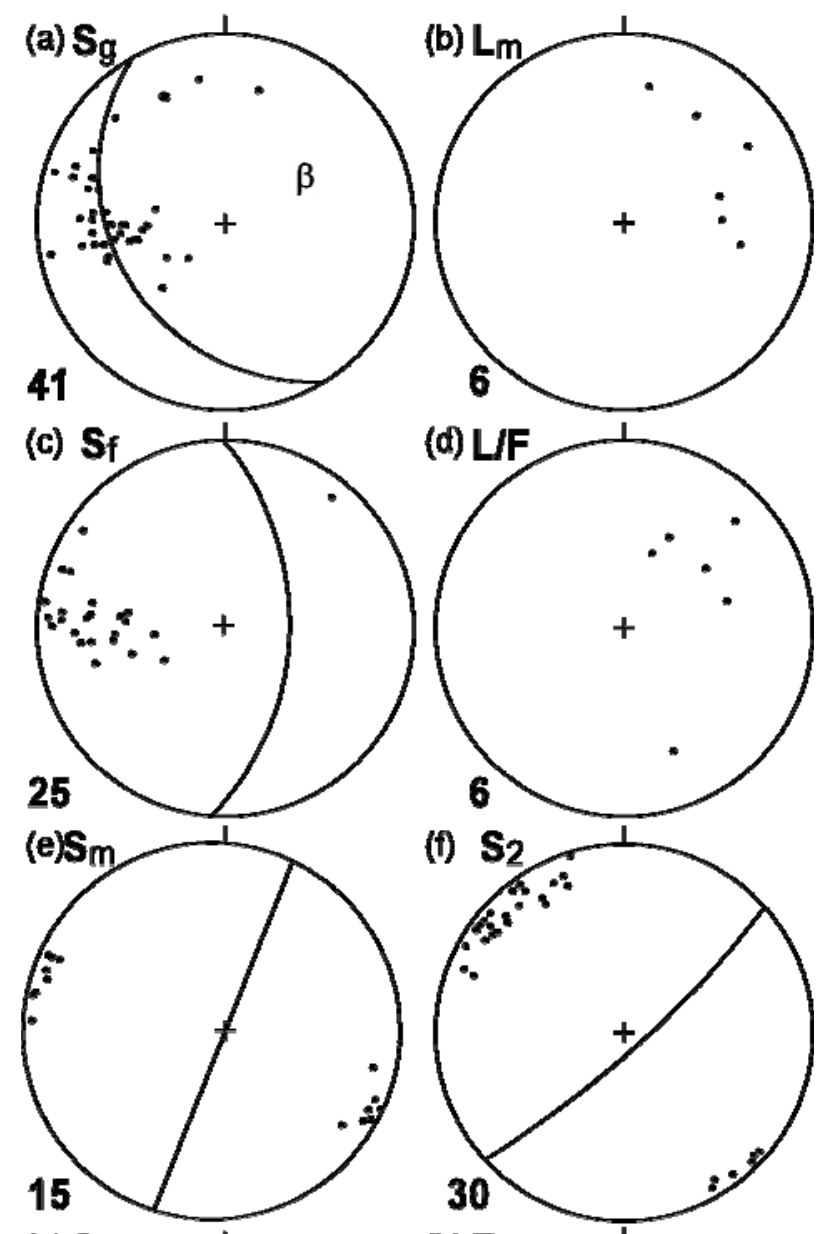

(f) $\mathrm{S}$
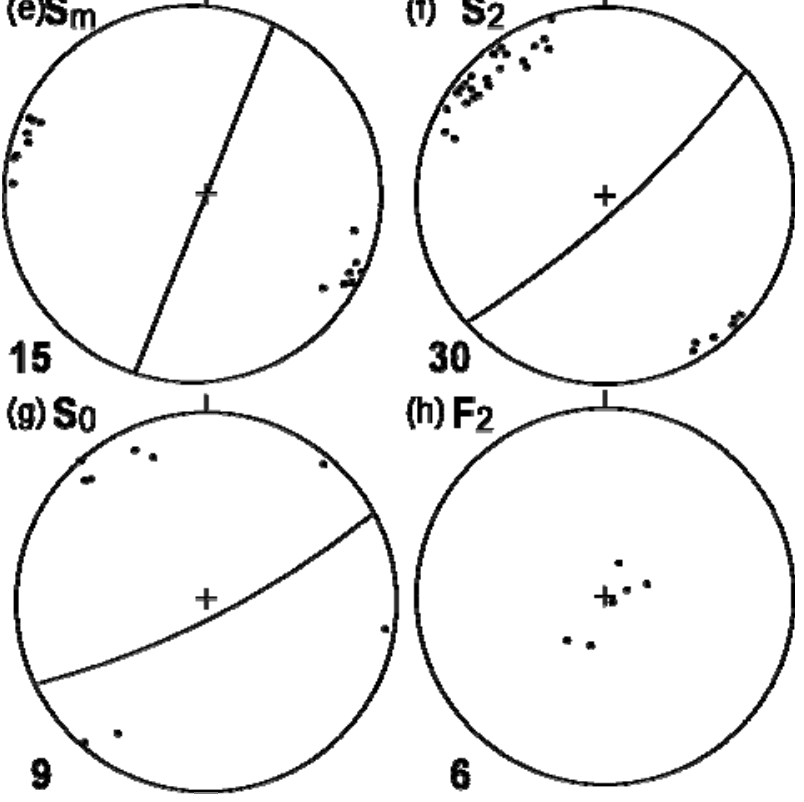

(h) $\mathrm{F}_{2}$

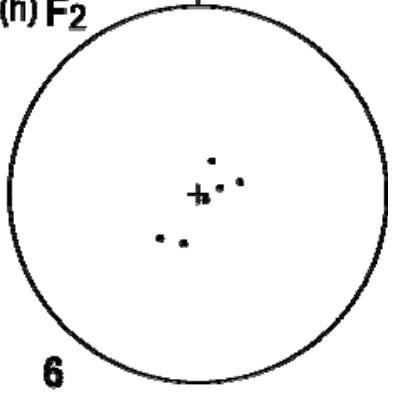

Figure 4 Lower hemisphere equal area stereographic projections of structural data from the 'The Lynd' and the southern part of the Balcooma Mylonite Zone. Number of measurements shown at lower left of each stereonet. (a) Poles to gneissic layering $\left(\mathrm{S}_{\mathrm{g}}\right)$ in the Oasis Metamorphics $-\beta$ axis $49^{\circ} / 059^{\circ}$. (b) $\mathrm{L}_{\mathrm{m}}$ (mineral lineation). (c) Poles to foliation $\left(\mathrm{S}_{\mathrm{f}}\right)$ in granitic segregations and axial planes to folds in gneissic layering of the Oasis Metamorphics - mean $61^{\circ} / 091^{\circ}$. (d) Lineation (L) in granitic segregations and folds (F) in $\mathrm{S}_{\mathrm{g}}$ in the Oasis Metamorphics. (e) Poles to mylonitic layering $\left(\mathrm{S}_{\mathrm{m}}\right)$ in Balcooma Mylonite Zone - mean $89^{\circ} / 112^{\circ}$. (f)-(h) Structural data from east of Balcooma Mylonite Zone. (f) Poles to $\mathrm{S}_{2}$ foliation - mean $83^{\circ} / 138^{\circ}$. (g) Poles to bedding $\left(\mathrm{S}_{0}\right)-$ mean $82^{\circ} / 152^{\circ}$. (h) $\mathrm{F}_{2}$ fold axes and $\mathrm{L}_{2}$ intersection lineations - mean $85^{\circ} / 131^{\circ}$. 

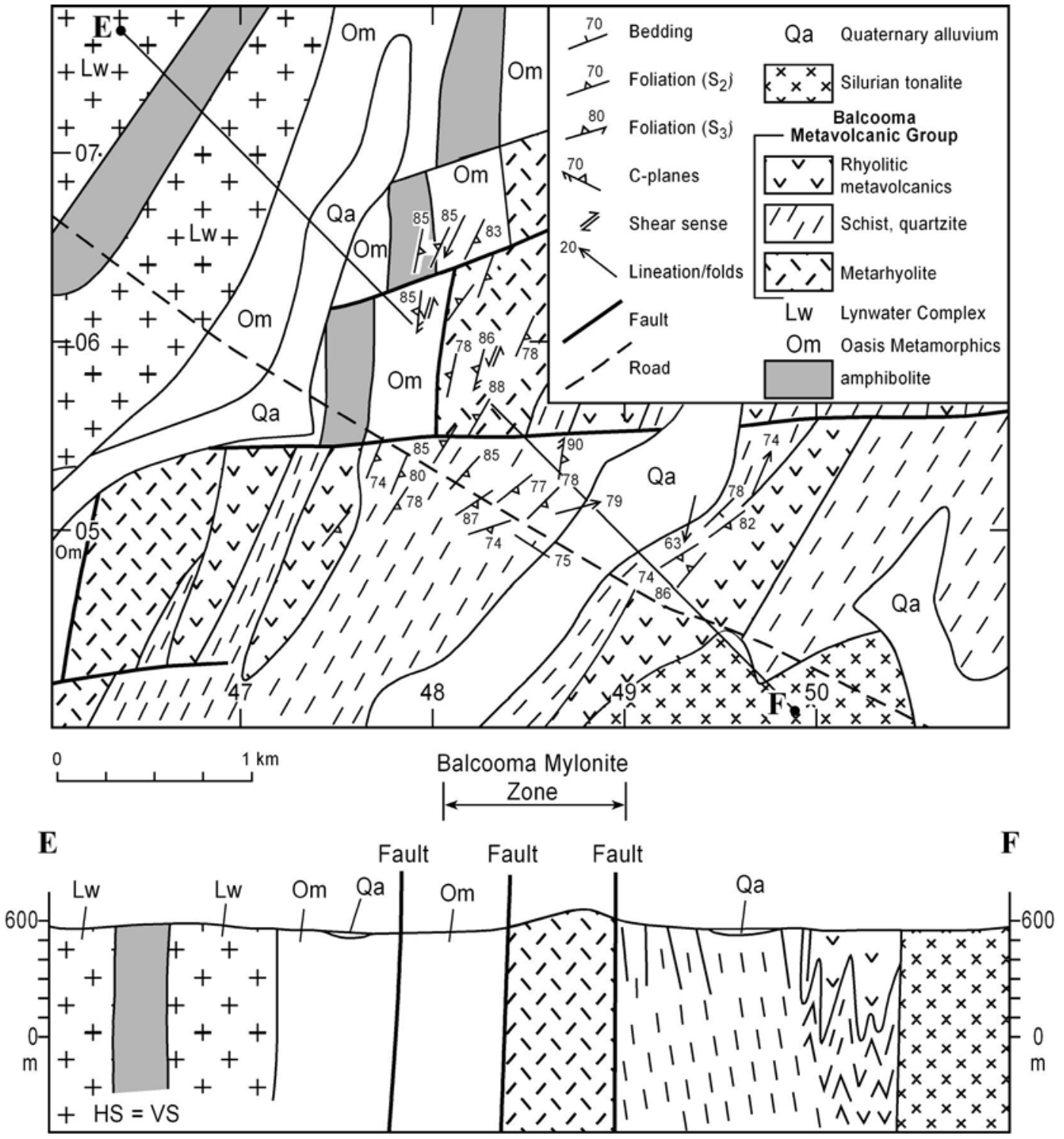

Figure 5 Detailed map and cross section EF for the southern part of the Balcooma Mylonite zone. 

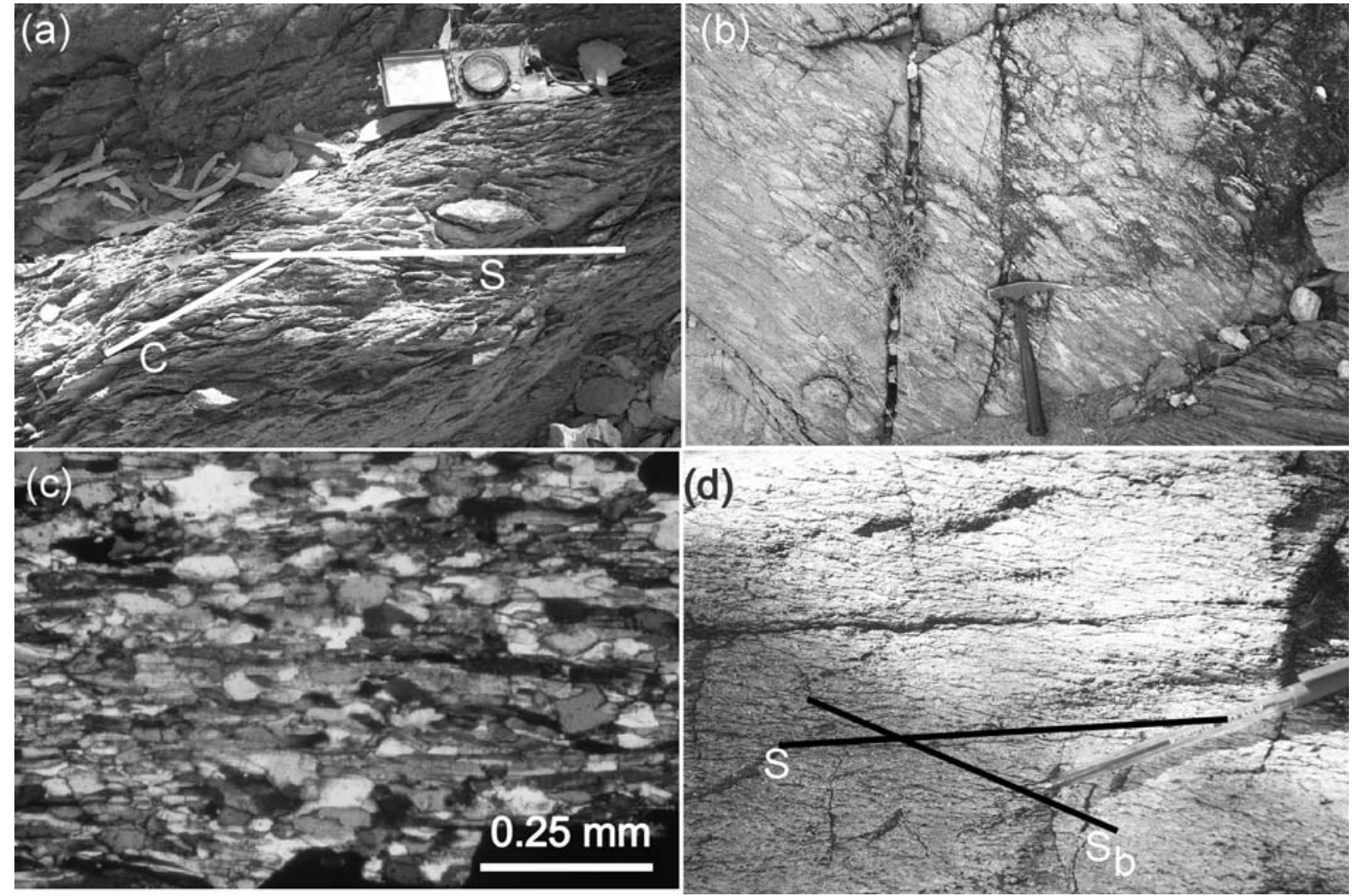

Figure 6 Photographs of structures from the Balcooma and Lucky Creek domains [grid references are to Conjuboy (7860) 1:100 000 sheet]. (a) S-C planes in mylonitised rhyolitic volcanic rocks in the Balcooma Mylonite Zone (247966 7906311). (b) Flattened fragments within the $\mathrm{S}_{2}$ foliation in Eland Metavolcanics (266451 7899920). (c) Photomicrograph of amphibolite from the Lugano Metamorphics with foliated hornblende, plagioclase and magnetite (sample LG27, 264263 7898724). Cross-polarised light. (d) Dextral shear bands $(\mathrm{Sb})$ in the Eland Metavolcanics (same location as (b)). 

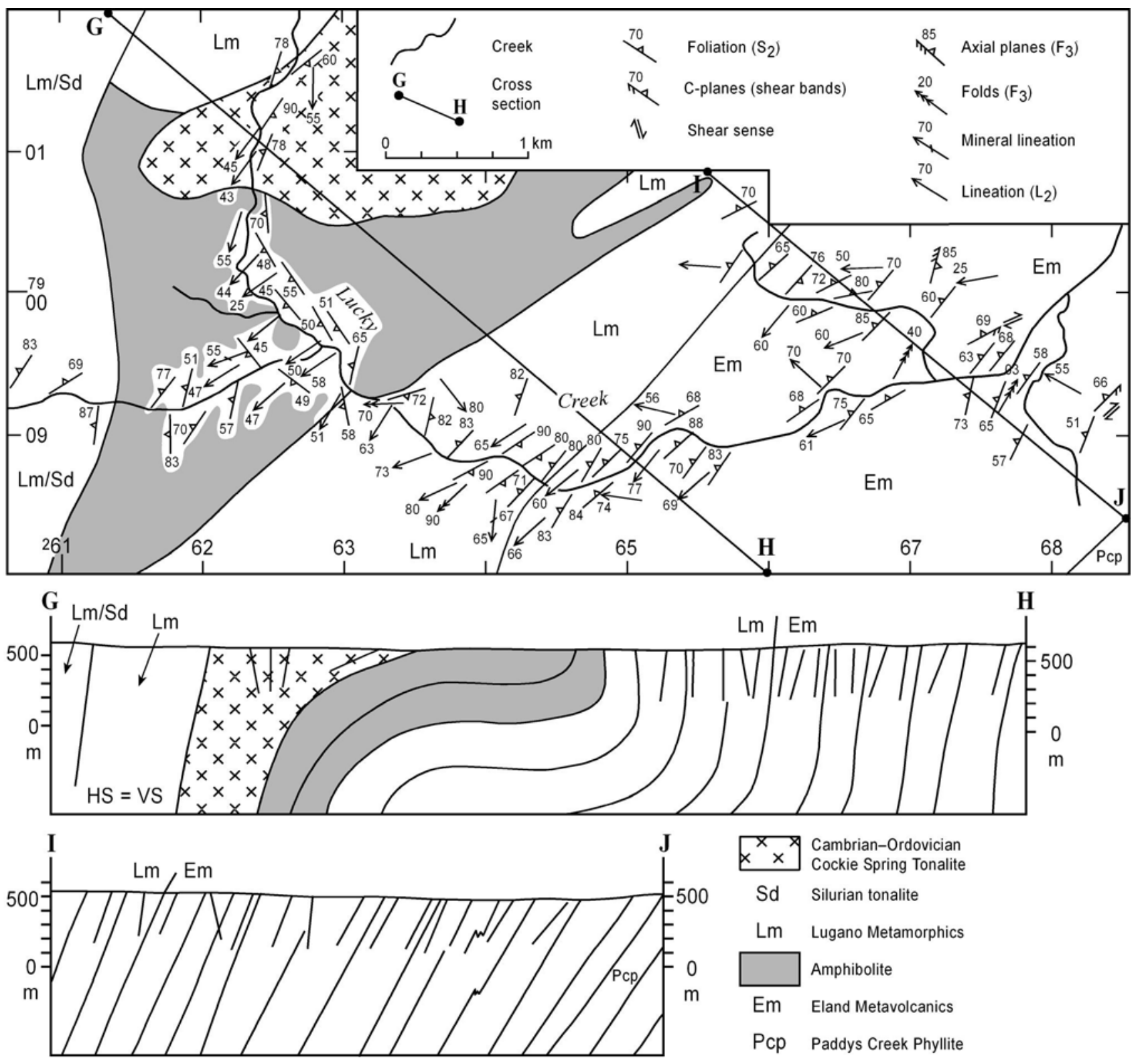

Figure 7 Detailed map of the Lucky Creek area with cross sections GH and IJ. 

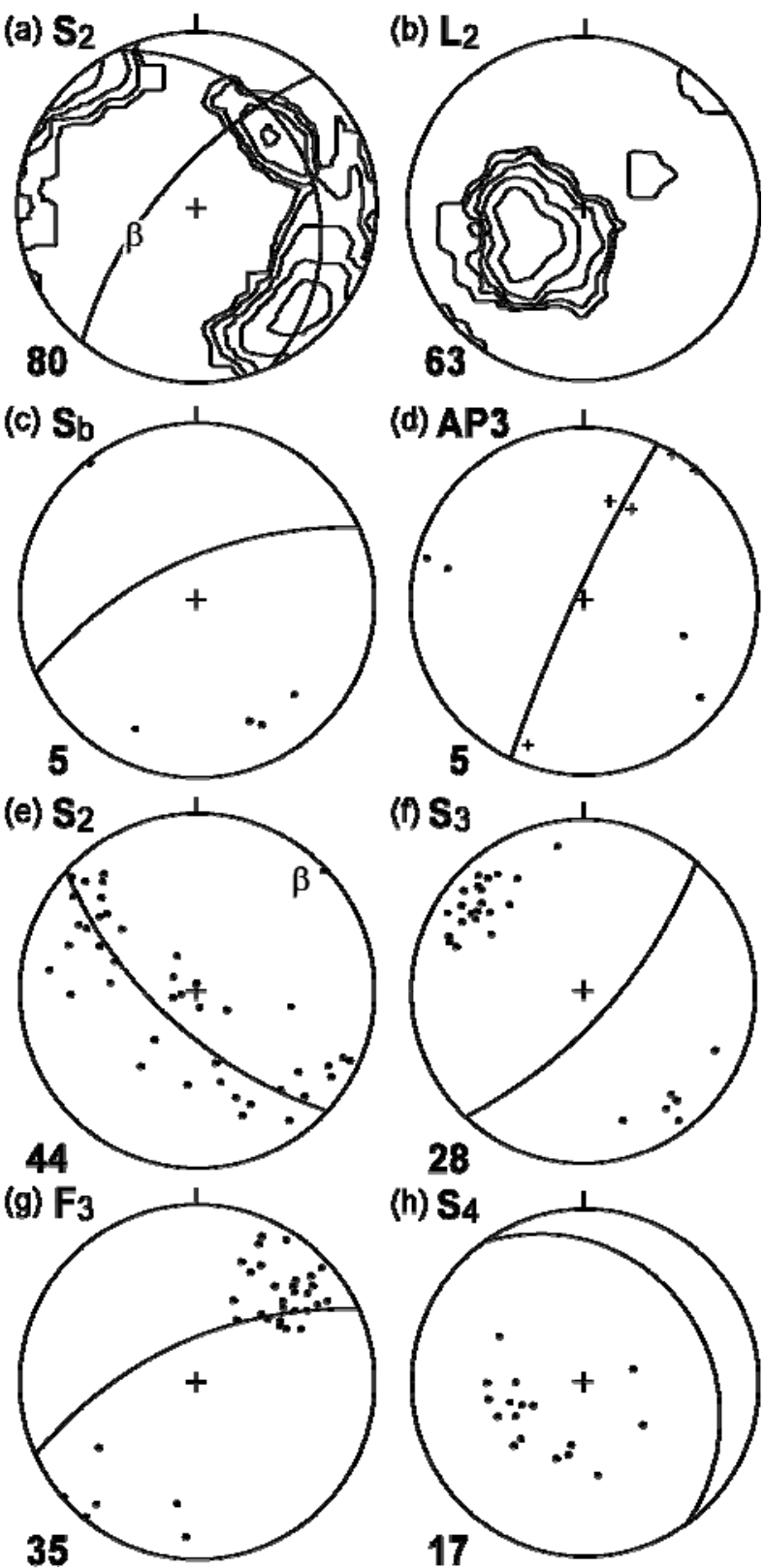

Figure 8 Lower hemisphere equal area stereographic projections of structural data from the Lugano Metamorphics and Eland Metavolcanics (a)-(d). Number of measurements shown at lower left of each stereonet. (a) Poles to $\mathrm{S}_{2}$ foliation in the Lugano Metamorphics and Eland Metavolcanics - mean $73^{\circ} / 310^{\circ}, \beta$-axis $55^{\circ} / 245^{\circ}$, contours at $1,2,4,8$ and $16 \%$ per $1 \%$ area. (b) $\mathrm{L}_{2}$ (intersection lineation, fold axes, mineral lineation) - mean $61^{\circ} / 242^{\circ}$, contours at 1,2 , 4,8 and $16 \%$ per $1 \%$ area. (c) Shear bands (dextral) - mean $71^{\circ} / 335^{\circ}$. (d) Poles to AP3 (AP = axial plane, dots - axial planes), mean $=86^{\circ} / 295^{\circ}$. $F_{3}$ fold axes (crosses). Both 5 measurements each. (e)-(h) Structural data from the Paddy Creek Phyllite (e) Poles to $S_{2}$ in the Paddys Creek Phyllite, $\beta$-axis $17^{\circ} / 043^{\circ}$. (f) Poles to $S_{3}-$ mean $76^{\circ} / 132^{\circ}$. (g) $F_{3}-$ mean $23^{\circ} / 044^{\circ}$. (h) Poles to $\mathrm{S}_{4}-$ mean $29^{\circ} / 054^{\circ}$. 


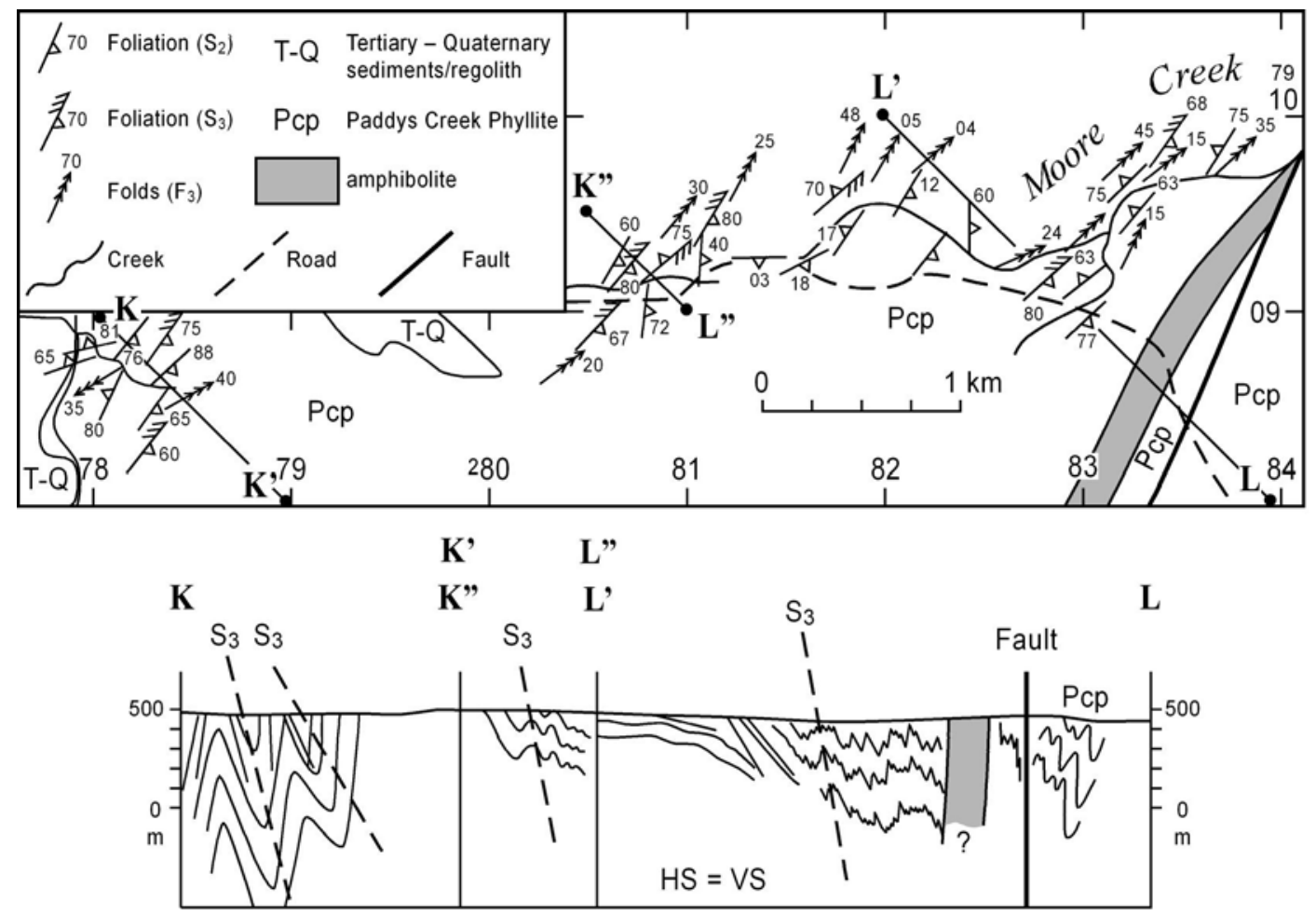

Figure 9 Detailed map of the Paddys Creek area and cross section KL.
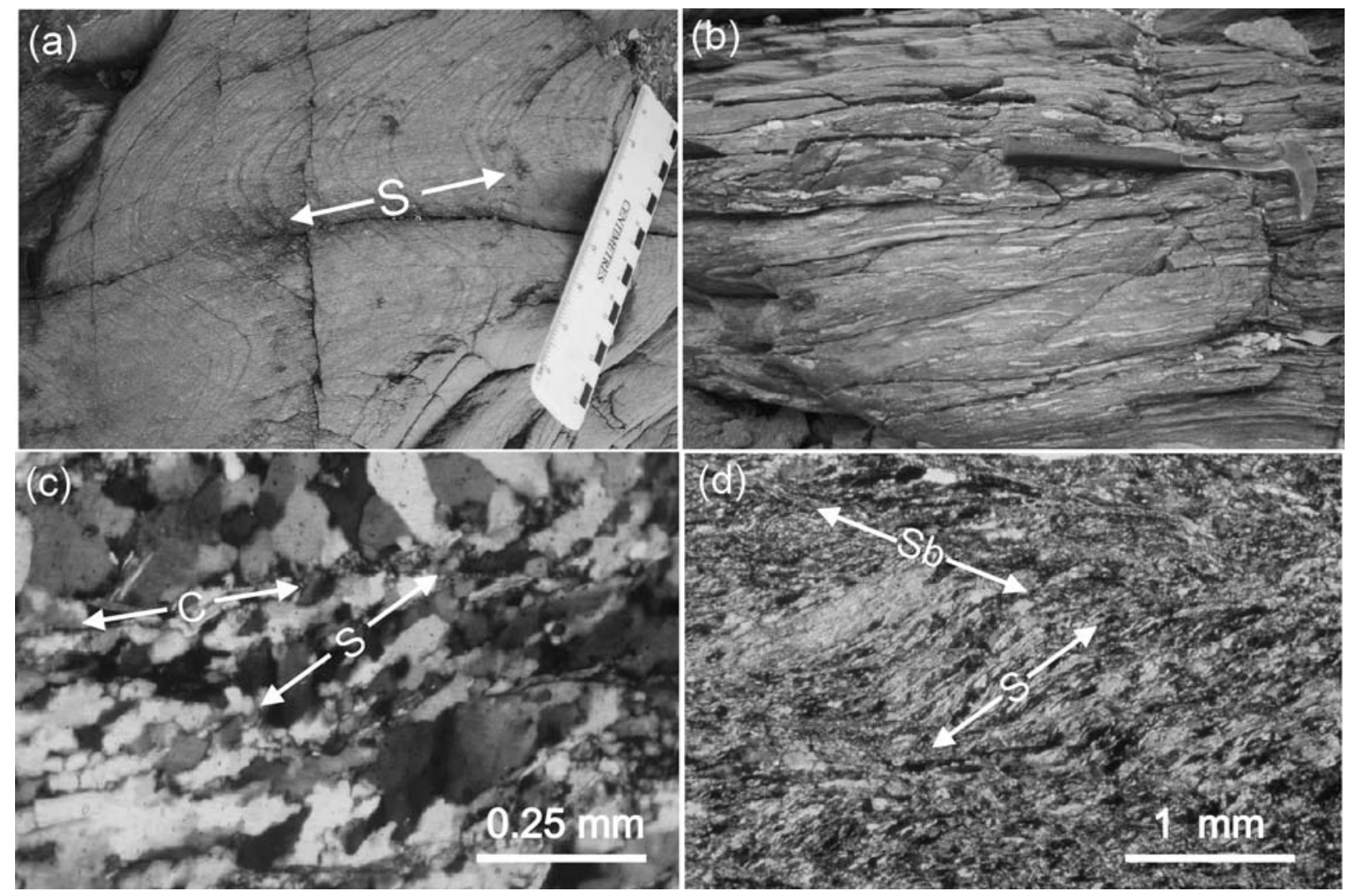

Figure 10 Photographs of structures from the Paddys Creek and Halls Reward domains [grid references are to Conjuboy (7860) 1:100 000 sheet]. (a) $\mathrm{S}_{2}$ foliation folded by $\mathrm{F}_{3}$ folds with axial planar crenulation cleavage (scale - $15 \mathrm{~cm}$ rule, Moore Creek, 283300 7909645). (b) Boudinaged layering in $\mathrm{S}_{2}$ foliation, Paddys Creek Phyllite (same location as (b)). (c) $\mathrm{S}$ and $\mathrm{C}$ 
planes indicating west-over-east shearing along the Nickel Mine Fault (sample LG264, 2816307804440 ). (d) Shear bands (Sb), which are sub-horizontal in the field, have a top to the west (top to right in photomicrograph) sense of shear (sample LG279, 284835 7899250).
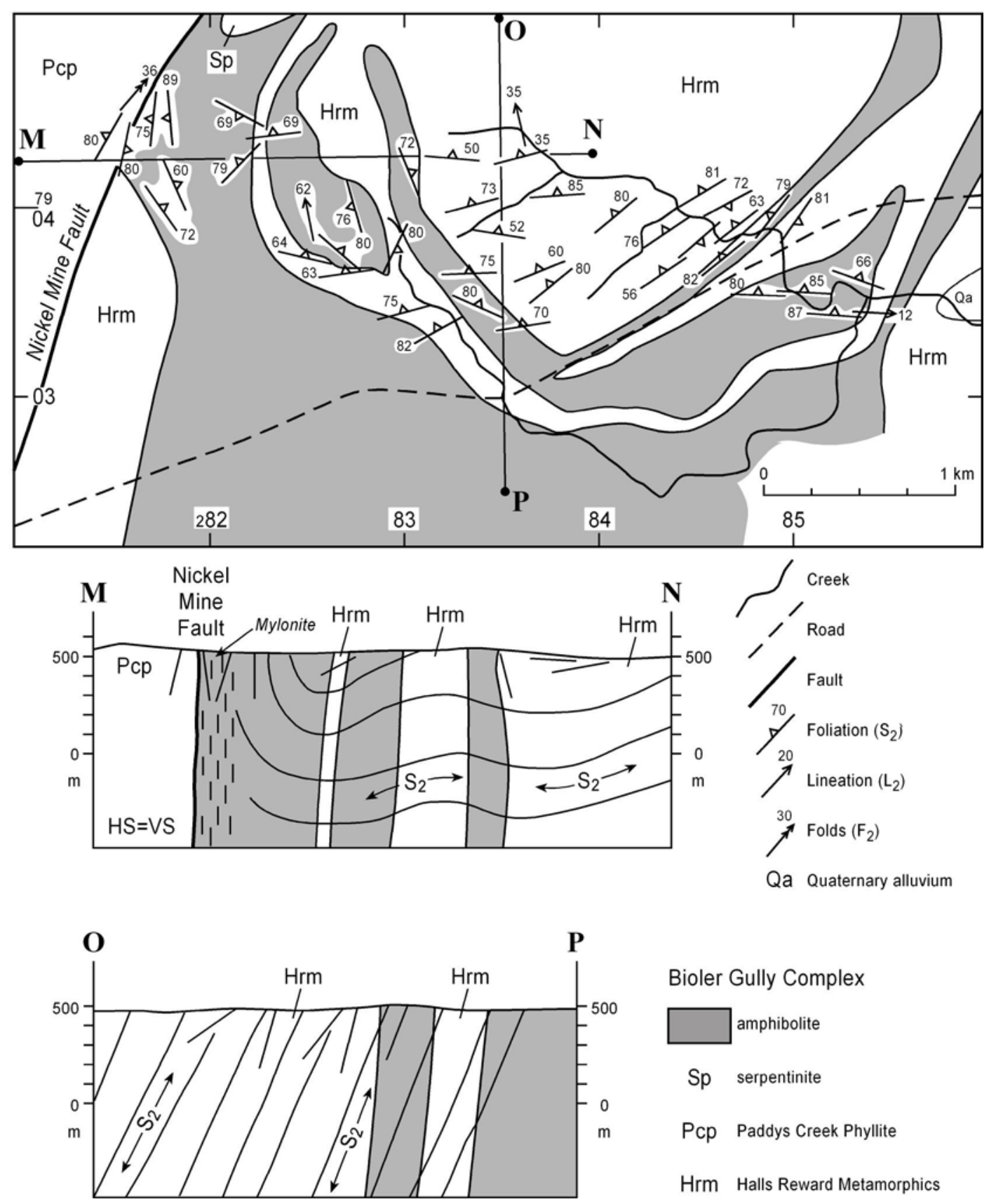

Bioler Gully Complex

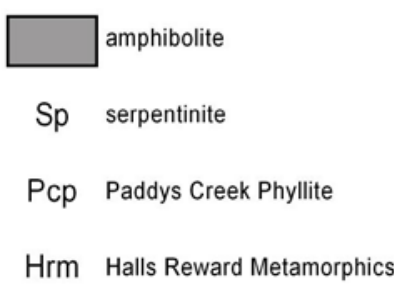

Figure 11 Detailed map of the Gray Creek Complex and Halls Reward Metamorphics in the Stenhouse Creek area and cross sections MN and OP. 

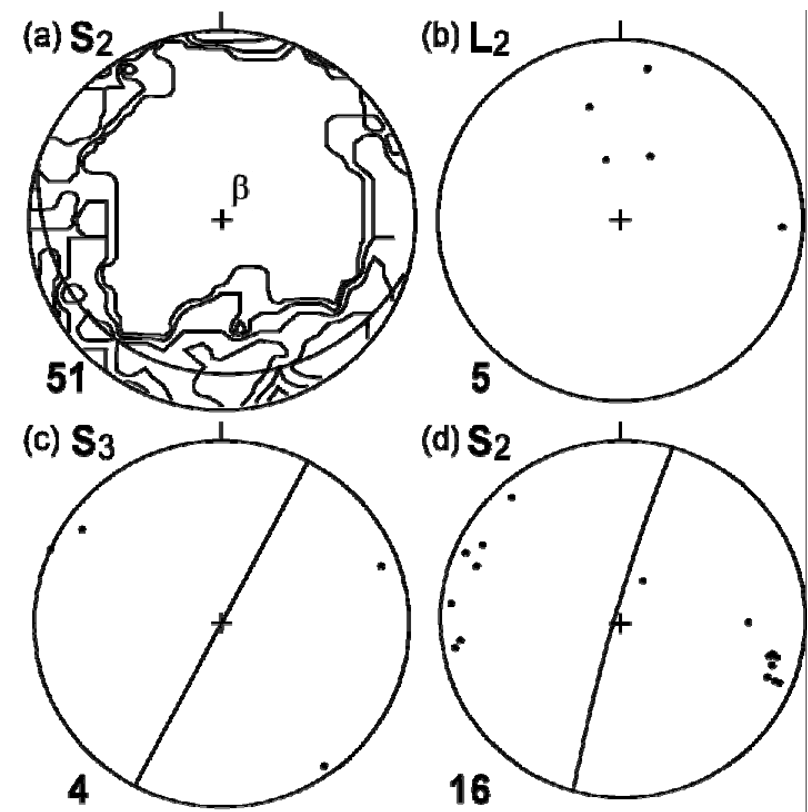

(d) $\mathbf{S}_{2}$
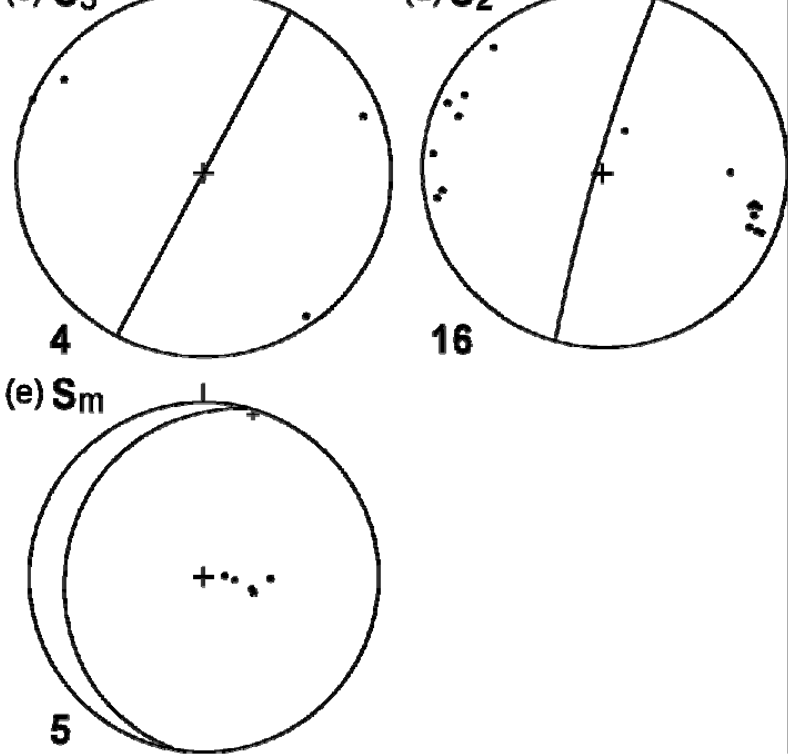

Figure 12 Lower hemisphere equal area stereographic projections of structural data from the Stenhouse Creek area and mylonite zones in the region. Number of measurements shown at lower left of each stereonet. (a) Poles to $\mathrm{S}_{2}-\beta$-axis $71^{\circ} / 016^{\circ}$, contours at $1,2,4$ and $8 \%$ per $1 \%$ area. (b) $\mathrm{L}_{2}-$ mean $45^{\circ} / 005^{\circ}$. (c) Poles to $\mathrm{S}_{3}-$ mean $90^{\circ} / 298^{\circ}$. (d) Greenvale railway poles to $\mathrm{S}_{2}$ - mean $86^{\circ} / 286^{\circ}$. (e) Greenvale pipeline track - poles to $\mathrm{S}_{\mathrm{m}}$ (dots) - mean $21^{\circ} / 280^{\circ} . \mathrm{L}_{\mathrm{m}}$ (crosses). 

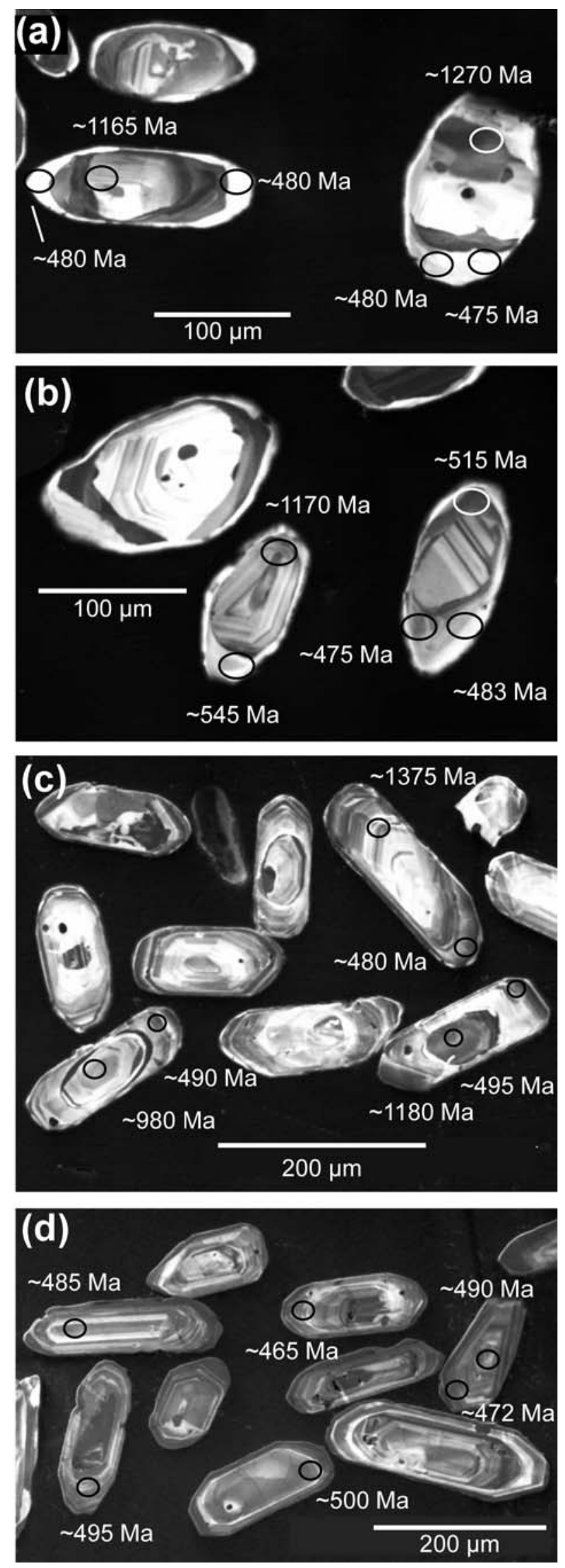

Figure 13 Representative CL images of the zircon grains analysed by SHRIMP: $(a, b)$ paragneiss sample IWGT016 - images highlight the bright luminescent metamorphic rims 
developed on the zoned igneous, inherited older cores; (c) orthogneiss sample IWGT238 image shows dominantly oscillatory zoned igneous zircon, with in some grains inherited zoned igneous cores; and (d) orthogneiss sample IWGT207 - image highlights the oscillatory zoned igneous nature of the zircon.
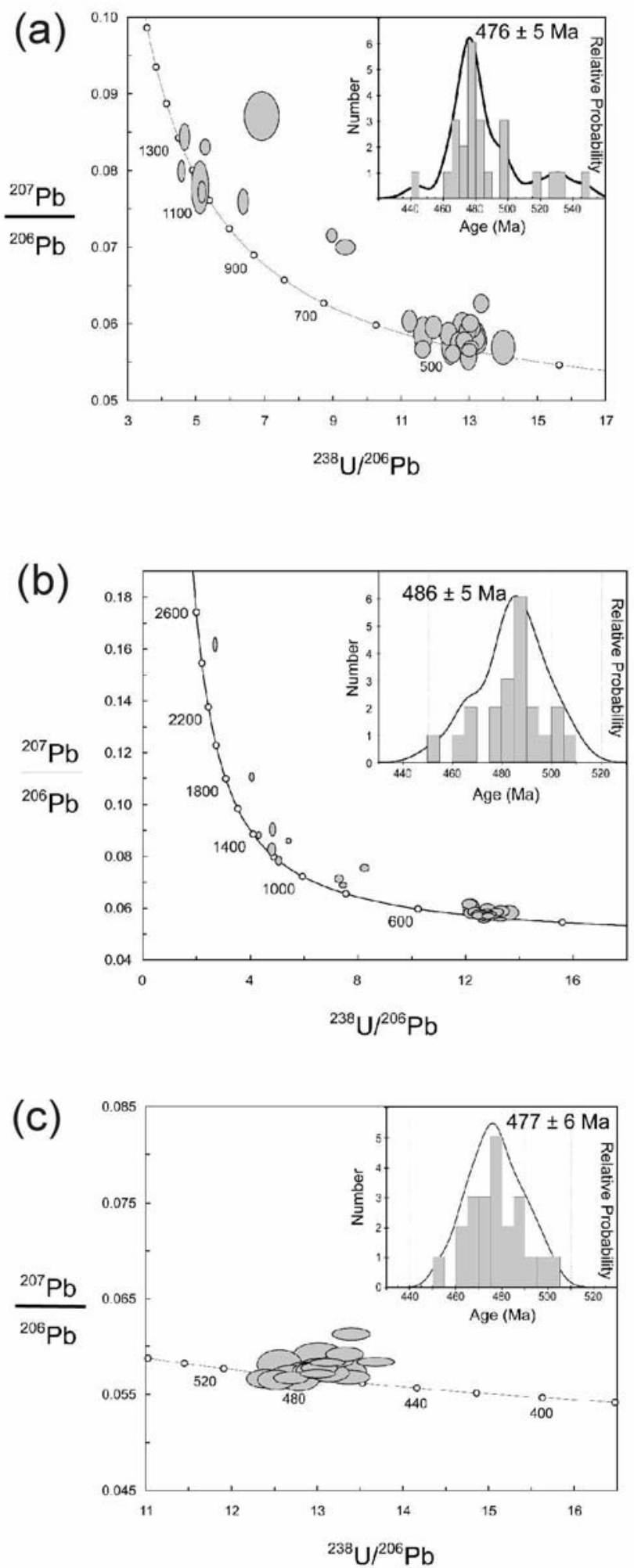
Figure 14 Tera and Wasserburg Concordia plots and histogram of U-Pb ages with superimposed probability distribution for samples (a) IWGT016 (paragneiss) from the Oasis Metamorphics (241380 7913120 Conjuboy (7860) 1:100 000 sheet), (b) IWGT238 (orthogneiss) from the Lynwater Complex (245100 7912730) Conjuboy (7860) 1:100 000 sheet) and (c) IWGT207 (orthogneiss) from the Lynwater Complex (247175 7912000 Conjuboy (7860) 1:100 000 sheet).

(a) Latest Cambrian to Early Ordovician

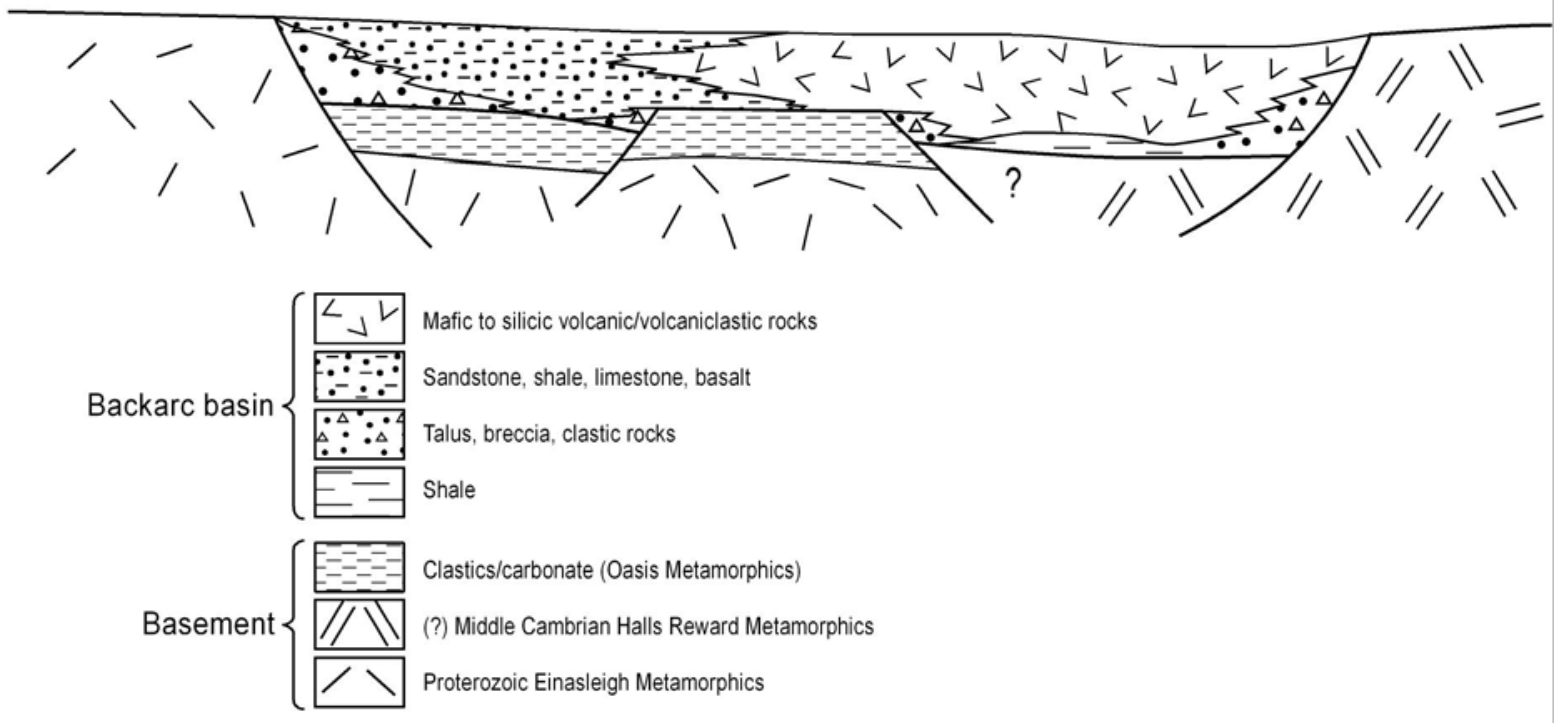

(b)
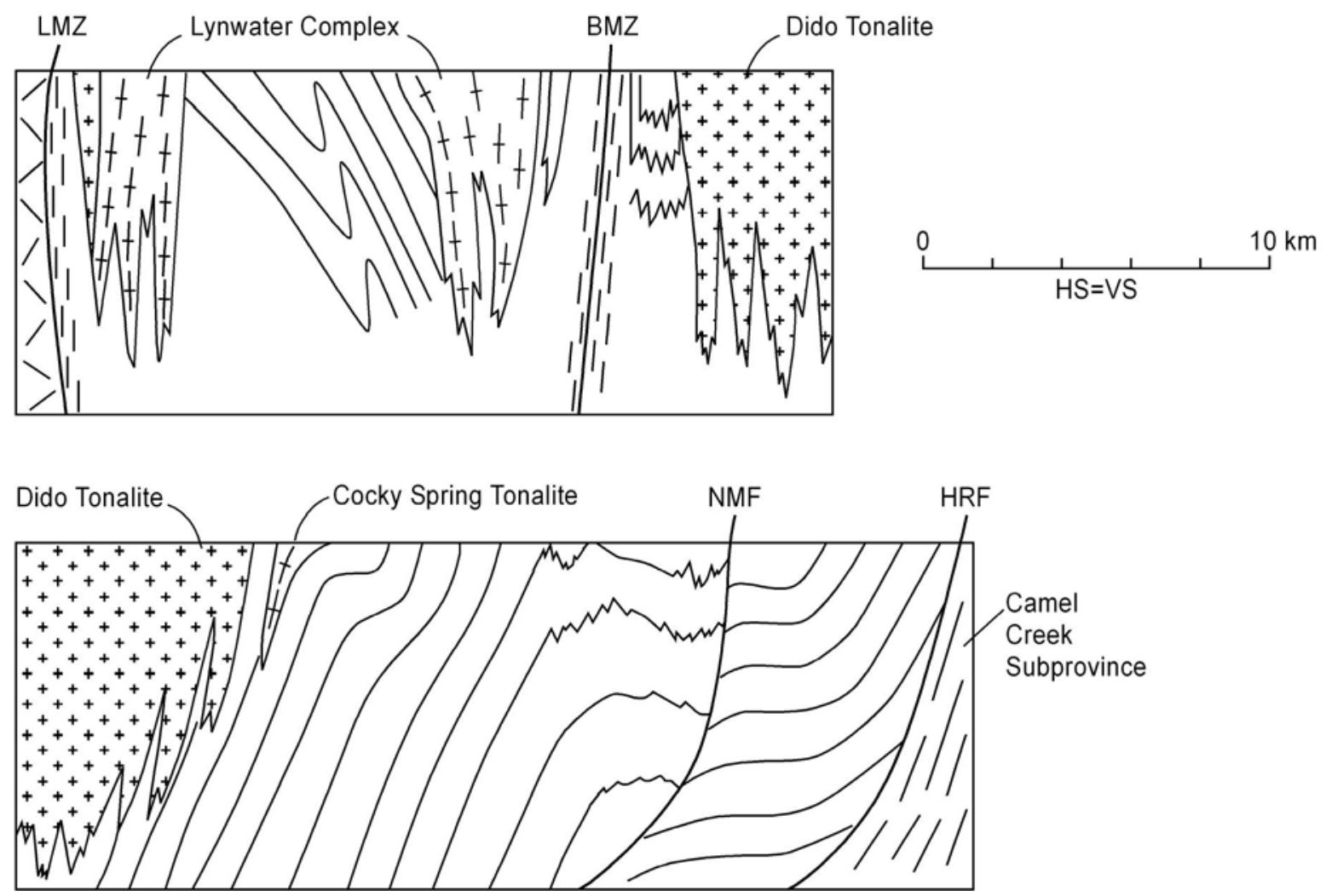

Figure 15 Schematic cross sections displaying the development of the Greenvale Province. (a) Latest Cambrian to Earliest Ordovician phase of backarc igneous activity and 
sedimentation in an extending backarc basin (490-470 Ma). (b) Present-day cross section showing upright folding in foliation and reactivation of early faults during the Early Silurian contractional event.

\section{TABLES}

Table 1 Rock units in domains along the transect across the Greenvale Province (Withnall 1989, 2004; Withnall et al. 1991, 1997, 2002).

Table 1 Rock units in domains along the transect across the Greenvale Province (Withnall 1989, 2004; Withnall et al. 1991, 1997, 2002).

\begin{tabular}{|c|c|c|c|c|c|}
\hline Domain & Lynd & Balcooma & Lucky Creek & Paddys Creek & Halls Reward \\
\hline $\begin{array}{l}\text { Units and Rock } \\
\text { Types }\end{array}$ & $\begin{array}{l}\text { Oasis Metamorphics - } 3 \\
\text { subunits (from base up) (1) } \\
\text { O1 - calc-silicate gneiss, } \\
\text { (2) O2 - amphibolite with } \\
\text { lesser biotite schist, (3) O3 } \\
\text { biotite gneiss with less } \\
\text { common amphibolite, calc- } \\
\text { silicate gneiss, and lenses } \\
\text { of dolomitic marble. } \\
\text { Lynwater Complex - } \\
\text { hornblende-bearing and two- } \\
\text { mica granitoids grading into } \\
\text { orthogneiss. Less strongly } \\
\text { foliated Silurian McKinnons } \\
\text { Creek Granite. }\end{array}$ & $\begin{array}{l}\text { Balcooma Metavolcanic } \\
\text { Group - lower Clayhole } \\
\text { Schist with massive pelite } \\
\text { and quartzose } \\
\text { - metasandstone, overlain by } \\
\text { massive metarhyolitic } \\
\text { volcaniclastics with } \\
\text { prominent metarhyolite in } \\
\text { west, some metadolerite } \\
\text { and meta-andesite. Dido } \\
\text { - Tonalite - biotite and biotite- } \\
\text { hornblende bearing tonalite } \\
\text { pluton. }\end{array}$ & $\begin{array}{l}\text { Lucky Creek Metamorphic Group - } \\
\text { divided into Lugano Metamorphics with } \\
\text { amphibolite unit in west (with relict } \\
\text { pillow lavas, hyaloclastites and } \\
\text { amygdales), a mixed unit of } \\
\text { amphibolite, metarhyolite and } \\
\text { metasedimentary rocks of the Lugano } \\
\text { Metamorphics in the centre, and mafic } \\
\text { to silicic metavolcanics and } \\
\text { metavolcaniclastics of the Eland } \\
\text { Metavolcanics in the east. } \\
\text { Metamorphosed clastic rocks (derived } \\
\text { from feldspathic sandstone, breccia, } \\
\text { conglomerate, chert and limestone) } \\
\text { occur in Lugano Metamorphics and } \\
\text { Eland Metavolcanics. Cockie Spring } \\
\text { Tonalite - hornblende and biotite bearing } \\
\text { tonalite with minor amphibolite. }\end{array}$ & $\begin{array}{l}\text { Paddys Creek } \\
\text { Phyllite - } \\
\text { pelite, lesser } \\
\text { quartzite }\end{array}$ & $\begin{array}{l}\text { Halls Reward } \\
\text { Metamorphics - coarse- } \\
\text { grained muscovite-quartz } \\
\text { schist with biotite, } \\
\text { sillimanite and garnet. } \\
\text { Bioler Gully Complex - } \\
\text { Sandalwood Serpentinite } \\
\text { and Stenhouse Creek } \\
\text { Amphibolite - layered } \\
\text { amphibolite and } \\
\text { metagabbro. Units are } \\
\text { intermixed at outcrop to } \\
\text { map-scales. }\end{array}$ \\
\hline Metamorphism & $\begin{array}{l}\text { Upper amphibolite facies } \\
\text { shown by co-existing } \\
\text { hornblende and diopside in } \\
\text { calc-silicate gneiss, and } \\
\text { widespread granitoid and } \\
\text { pegmatite segregrations }\end{array}$ & $\begin{array}{l}\text { Amphibolite facies in } \\
\text { Balcooma Metavolcanic } \\
\text { Group - andalusite, } \\
\text { staurolite and garnet in } \\
\text { addition to widespread } \\
\text { biotite }\end{array}$ & $\begin{array}{l}\text { Amphibolite to greenschist facies - } \\
\text { hornblende in amphibolite, chlorite, } \\
\text { actinolite and muscovite in greenschist } \\
\text { Eland Metavolcanics. Metamorphic } \\
\text { grade decreases eastwards. }\end{array}$ & $\begin{array}{l}\text { Greenschist } \\
\text { facies - } \\
\text { muscovite, } \\
\text { quartz and } \\
\text { lesser chlorite }\end{array}$ & $\begin{array}{l}\text { Halls Reward } \\
\text { Metamorphics - amphibolite } \\
\text { facies - biotite, garnet, } \\
\text { sillimanite, abundant } \\
\text { leucogranite and pegmatite. } \\
\text { Stenhouse Creek } \\
\text { Amphibolite - hornblende. }\end{array}$ \\
\hline Age constraints & $\begin{array}{l}\text { Oasis Metamorphics - } \\
\text { detrital zircons (U-Pb ages) } \\
\text { of } 540-520 \mathrm{Ma} \text {, } \\
\text { metamorphic rims } 476 \pm 5 \\
\text { Ma (Early Ordovician). } \\
\text { Lynwater Complex - U-Pb } \\
\text { zircon ages of } 486 \pm 5 \mathrm{Ma} \\
\text { and } 477 \pm 6 \mathrm{Ma} \text { (Early } \\
\text { Ordovician). Depositional } \\
\text { age of Cambrian to Early } \\
\text { Ordovician for the Oasis } \\
\text { Metamorphics. }\end{array}$ & $\begin{array}{l}\text { Balcooma Metavolcanic } \\
\text { Group - U-Pb zircon age } \\
471 \pm 4 \mathrm{Ma} \text { - Ordovician } \\
\text { age (Withnall et al. 1991). } \\
\text { Dido Tonalite - U-Pb zircon } \\
\text { age of } 431 \pm 7 \mathrm{Ma} \text { - Early } \\
\text { Silurian (Bain et al. 1997). }\end{array}$ & $\begin{array}{l}\text { Considered Early Palaeozoic - no } \\
\text { zircon ages have so far been obtained }\end{array}$ & $\begin{array}{l}\text { Considered } \\
\text { Early } \\
\text { Palaeozoic - } \\
\text { no zircon } \\
\text { ages have so } \\
\text { far been } \\
\text { obtained }\end{array}$ & $\begin{array}{l}\text { U-Th-Pb chemical dating of } \\
\text { zircon and monazite, } \mathrm{Rb} / \mathrm{Sr} \\
\text { ages of schist and } \mathrm{K} / \mathrm{Ar} \\
\text { dating of muscovite indicate } \\
\text { ages of ca } 500-510 \mathrm{Ma} \\
\text { (Nishiya et al. 2003) - } \\
\text { Middle Cambrian, } \\
\text { considered a metamorphic } \\
\text { age }\end{array}$ \\
\hline Interpretation & $\begin{array}{l}\text { Shallow marine clastic } \\
\text { succession with mafic } \\
\text { volcanics and/or intrusions. } \\
\text { Lynwater Complex - } \\
\text { intrusions of tonalite, } \\
\text { granodiorite and granite. }\end{array}$ & $\begin{array}{l}\text { Dominant silicic volcanism } \\
\text { and fine-grained } \\
\text { sedimentation }\end{array}$ & $\begin{array}{l}\text { Silicic to mafic volcanism (bimodal) with } \\
\text { associated sedimentation }\end{array}$ & $\begin{array}{l}\text { Fine-grained } \\
\text { sedimentation }\end{array}$ & $\begin{array}{l}\text { Fine-grained sedimentation } \\
\text { and mafic to ultramafic } \\
\text { intrusive activity }\end{array}$ \\
\hline
\end{tabular}

Table 2 Deformations in domains along the transect across the Greenvale Province (including data from Withnall 1989). 
Table 2 Deformations in domains along the transect across the Greenvale Province (including data from Withnall 1989).

\begin{tabular}{|c|c|c|c|c|c|}
\hline Domain & Lynd & Balcooma & Lucky Creek & Paddys Creek & Halls Reward \\
\hline Deformation & $\mathrm{D}_{1}$ & $\mathrm{D}_{1}$ & $\mathrm{D}_{1}$ & $\mathrm{D}_{1}$ & $\mathrm{D}_{1}$ \\
\hline $\begin{array}{l}\text { Structural } \\
\text { elements }\end{array}$ & $S_{g}, L_{m}$ & $\mathrm{~S}_{1}$ & $\mathrm{~S}_{1}$ & $\mathrm{~S}_{1}, \mathrm{~F}_{1}$ & $\mathrm{~S}_{1}$ \\
\hline Description & $\begin{array}{l}\text { Main compositional } \\
\text { layering, foliation and } \\
\text { rare mineral lineation } \\
\text { (amphibole, biotite), } \\
\text { boudinaged amphibolite } \\
\text { and pegmatite layers }\end{array}$ & $\begin{array}{l}\text { Early foliation and } \\
\text { compositional layering } \\
\text { subparallel to bedding } \\
\text { and largely obliterated } \\
\text { by } \mathrm{S}_{2}\end{array}$ & $\begin{array}{l}\text { Rarely presenved } \mathrm{S}_{1} \text { foliation, } \\
\text { differentiated layering is locally } \\
\text { developed }\end{array}$ & $\begin{array}{l}\mathrm{S}_{1} \text { is a rarely preserved continuous } \\
\text { cleavage within } \mathrm{S}_{2} \text { microlithons }\end{array}$ & $\begin{array}{l}\text { Relict crenulations of } \mathrm{S}_{1} \\
\text { preserved in some } \\
\text { siliceous rocks }\end{array}$ \\
\hline Orientation & $\begin{array}{l}\text { Mainly steeply dipping } \\
\text { to east, lineation } \\
\text { plunges moderately } \\
\text { northeast }\end{array}$ & Subparallel to bedding & $\begin{array}{l}\text { Tightly folded and transposed } \\
\text { mainly subparallel to } S_{2}\end{array}$ & Transposed parallel to $S_{2}$ & $\begin{array}{l}\text { Largely transposed } \\
\text { parallel to } S_{2}\end{array}$ \\
\hline Deformation & $\mathrm{D}_{2}$ & $\mathrm{D}_{2}$ & $\mathrm{D}_{2}$ & $\mathrm{D}_{2}$ & $\mathrm{D}_{2}$ \\
\hline $\begin{array}{l}\text { Structural } \\
\text { elements }\end{array}$ & $\begin{array}{l}\mathrm{S}_{\mathrm{f}}, \mathrm{AP} 2, \mathrm{~F}_{2}, \mathrm{~L}_{2}, \text { (note } \\
\mathrm{AP}=\text { axial plane) }\end{array}$ & $\mathrm{S}_{2}, \mathrm{~F}_{2}, \mathrm{~L}_{2}$ & $\mathrm{~S}_{2}, \mathrm{~F}_{2,} \mathrm{~L}_{2}, \mathrm{~L}_{\mathrm{s}}$ & $\mathrm{S}_{2}, \mathrm{~F}_{2}$ & $\mathrm{~S}_{2}, \mathrm{~F}_{2}$ \\
\hline Description & $\begin{array}{l}\text { Sinusoidal to box- } \\
\text { shaped, open to near } \\
\text { isoclinal folds with } \\
\text { steeply inclined axial } \\
\text { planes, granitic veins } \\
\text { locally developed along } \\
\text { axial planes, weak } \\
\text { foliation in granitic veins } \\
\text { and along axial planes }\end{array}$ & $\begin{array}{l}\text { Crenulation cleavage } \\
\text { varying to a continuous } \\
\text { foliation defined by } \\
\text { aligned muscovite and } \\
\text { biotite with elongate } \\
\text { porphyoblasts of } \\
\text { andalusite(?), steeply } \\
\text { plunging tight to near } \\
\text { isoclinal folds }\end{array}$ & $\begin{array}{l}\mathrm{S}_{2} \text { is a well developed foliation } \\
\text { defined by aligned chlorite, } \\
\text { muscovite, quartz and amphibole in } \\
\text { metavolcanic units. } \mathrm{F}_{2} \text { folds are tight } \\
\text { to isoclinal in earlier compositional } \\
\text { layering. Pressure fringes, mineral } \\
\text { elongation (hornblende) and } \\
\text { elongate fragments indicate } \mathrm{L}_{2} \\
\text { intersection lineation is also a } \\
\text { stretching lineation. Boundinaged } \\
\text { veins of quartz occur in the foliation. }\end{array}$ & $\begin{array}{l}\mathrm{S}_{2} \text { is a well developed, laminar } \\
\text { crenulation cleavage with aligned } \\
\text { muscovite and quartz in cleavage } \\
\text { domains, microlithons up to } 1-2 \mathrm{~cm} \\
\text { in width, rare } \mathrm{S}_{1}-\mathrm{S}_{2} \text { intersection } \\
\text { lineation is found on } \mathrm{S}_{2} \text { surfaces. } \\
\text { Boudinaged veins of quartz occur in } \\
\text { the foliation. }\end{array}$ & $\begin{array}{l}\mathrm{S}_{2} \text { is a strong foliation in } \\
\text { amphibolite defined by } \\
\text { hornblende, and a } \\
\text { differentiated crenulation } \\
\text { cleavage in schist with } \\
\text { aligned muscovite and } \\
\text { biotite, intrafolial isoclinal } \\
\text { folds abound in places. } \\
\text { Exposed contacts } \\
\text { between main rock units } \\
\text { are at oblique to high } \\
\text { angles to the main } \\
\text { foliation. }\end{array}$ \\
\hline Orientation & $\begin{array}{l}S_{f} \text { is steeply dipping to } \\
\text { east with rare } F_{2} \text { folds } \\
\text { plunging moderately to } \\
\text { northeast }\end{array}$ & $\begin{array}{l}\mathrm{S}_{2} \text { is steeply dipping to } \\
\text { the northwest with a } \\
\text { northeast strike, } \mathrm{F}_{2} \\
\text { folds are steeply } \\
\text { plunging }\end{array}$ & $\begin{array}{l}S_{2} \text { is folded around open to broad } \\
\text { map-scale folds, pre- } D_{3} S_{2} \text { was } \\
\text { gently dipping to northwest }\end{array}$ & $\begin{array}{l}S_{2} \text { is folded around abundant } F_{3} \text { and } \\
F_{4} \text {, prior to } D_{3} S_{2} \text { was gently dipping } \\
\text { to the northeast }\end{array}$ & $\begin{array}{l}\mathrm{S}_{2} \text { is steeply dipping to } \\
\text { north and northwest with } \\
\text { common variations in } \\
\text { strike due to later refolding } \\
\text { and development of } \\
\text { intrafolial folds in } \mathrm{S}_{2} \text { during } \\
\mathrm{D}_{2}, \mathrm{~S}_{2} \text { dips steeply to } \\
\text { west in Greenvale railway } \\
\text { cuttings, } F_{2} \text { are variably } \\
\text { plunging to north }\end{array}$ \\
\hline Deformation & & $D_{3}$ & $\mathrm{D}_{3}$ & $\mathrm{D}_{3}$ and $\mathrm{D}_{4}$ & $\mathrm{D}_{3}$ \\
\hline $\begin{array}{l}\text { Structural } \\
\text { elements }\end{array}$ & & $\mathrm{S}_{3}$ and $\mathrm{F}_{3}$ & $\mathrm{AP} 3$ and $\mathrm{F}_{3}$ & $\mathrm{~S}_{3}$ and $\mathrm{F}_{3}, \mathrm{~S}_{4}$ and $\mathrm{F}_{4}$ & AP3 \\
\hline Description & & $\begin{array}{l}\mathrm{S}_{3} \text { is a weak crenulation } \\
\text { cleavage with no } \\
\text { associated } \\
\text { metamorphic mineral } \\
\text { growth }\end{array}$ & $\begin{array}{l}\text { Open to close, upright folds that } \\
\text { verge to east-southeast. No axial } \\
\text { planar structure is present. }\end{array}$ & $\begin{array}{l}\mathrm{F}_{3} \text { are open to close, upright folds } \\
\text { with } \mathrm{S}_{3} \text { axial planar crenulation } \\
\text { cleavage defined by dissolution } \\
\text { along limbs of microlithons. } \mathrm{F}_{4} \text { are } \\
\text { broad to open folds with weak } \mathrm{S}_{4} \\
\text { axial planar crenulation cleavage. }\end{array}$ & Broad to open kink bands \\
\hline Orientation & & $\begin{array}{l}\mathrm{S}_{3} \text { strikes easterly and } \\
\text { is steeply dipping }\end{array}$ & $\begin{array}{l}\text { AP3 strike north-northeast and dip } \\
\text { steeply, } F_{3} \text { have subhorizontal to } \\
\text { gentle plunges }\end{array}$ & $\begin{array}{l}F_{3} \text { are upright folds gently plunging } \\
\text { to northeast. } S_{3} \text { is dipping steeply } \\
\text { to southeast. } F_{4} \text { plunge gently to } \\
\text { northwest. } S_{4} \text { dips gently to } \\
\text { moderately to northeast. }\end{array}$ & $\begin{array}{l}\text { AP3 are steeply dipping } \\
\text { and northerly striking }\end{array}$ \\
\hline
\end{tabular}

\section{SUPPLEMENTARY TABLE}

Table 3 Summary of SHRIMP U-Pb zircon results. 


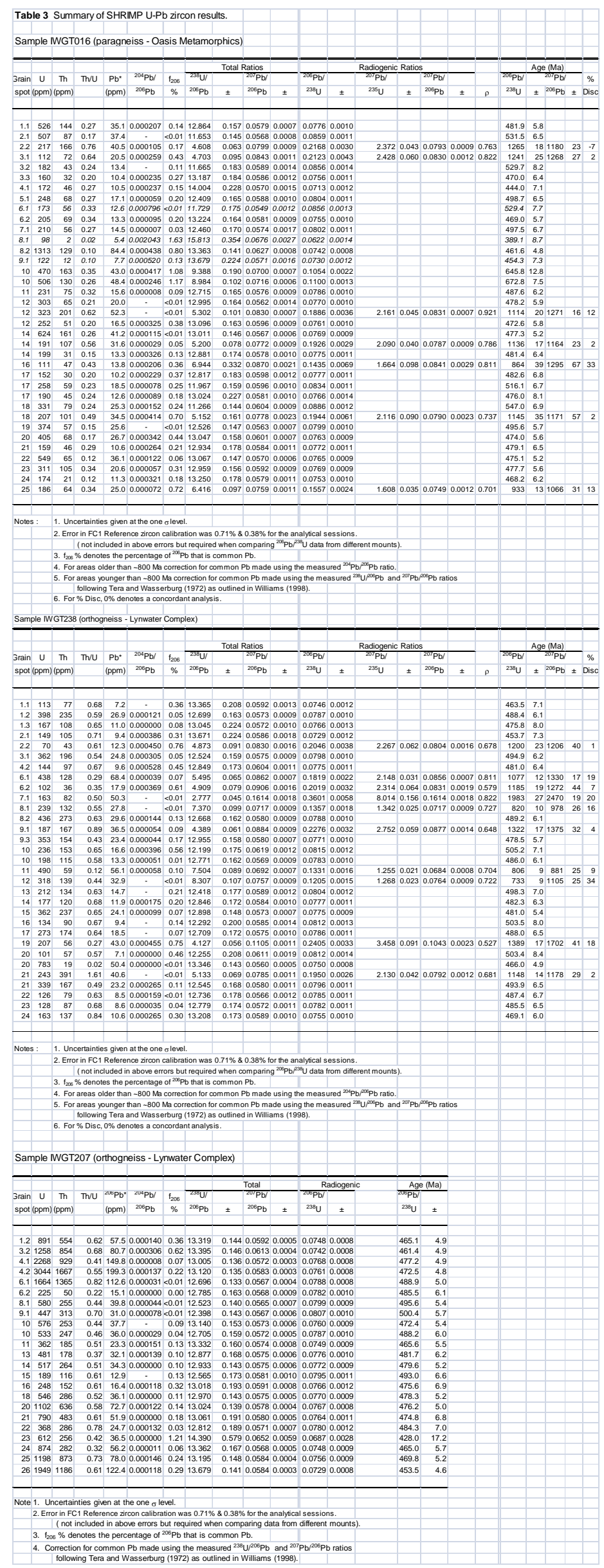

